\title{
Phytochemistry and Biological Activities of Iris Species Growing in Iraqi Kurdistan and Phenolic Constituents of the Traditional Plant Iris postii
}

\author{
Hawraz Ibrahim M. Amin ${ }^{1,2, *}$, , Faiq H. S. Hussain ${ }^{3}$, Soran K. Najmaldin ${ }^{4}$, Zaw Min Thu ${ }^{5}{ }^{\circledR}$, \\ Mohammed Farhad Ibrahim ${ }^{6}$, Gianluca Gilardoni ${ }^{7}$ (i) and Giovanni Vidari ${ }^{3,8, *}$ \\ 1 Dipartimento di Scienze del Farmaco, Università del Piemonte Orientale, Largo Donegani 2, \\ 28100 Novara, Italy \\ 2 Department of Chemistry, College of Science, Salahaddin University-Erbil, Erbil 44001, Kurdistan Region, Iraq \\ 3 Medical Analysis Department, Faculty of Science, Tishk International University, \\ Erbil 44001, Kurdistan Region, Iraq; faiq.hussain@tiu.edu.iq \\ 4 Biology Department, Faculty of Education, Tishk International University, Erbil 44001, Kurdistan Region, Iraq; \\ soran.kayfi@tiu.edu.iq \\ 5 Department of Chemistry, Kalay University, Kalay 03044, Myanmar; zawminthu87@gmail.com \\ 6 Department of Drug Science, University of Pavia, Viale Taramelli 10, 27100 Pavia, Italy; gardy1988@gmail.com \\ 7 Departamento de Química y Ciencias Exactas, Universidad Técnica Particular de Loja, Calle Marcelino \\ Champagnat s/n, Loja 110107, Ecuador; ggilardoni@utpl.edu.ec \\ 8 Dipartimento di Chimica, Università di Pavia, Via Taramelli 12, 27100 Pavia, Italy \\ * Correspondence: hawraz.mohammedamin@uniupo.it (H.I.M.A.); vidari@unipv.it (G.V.); \\ Tel.: +39-380-6359340 (H.I.M.A.); +39-334-3782582 (G.V.)
}

check for

updates

Citation: Amin, H.I.M.; Hussain, F.H.S.; Najmaldin, S.K.; Thu, Z.M.; Ibrahim, M.F.; Gilardoni, G.; Vidari, G. Phytochemistry and Biological Activities of Iris Species Growing in Iraqi Kurdistan and Phenolic Constituents of the Traditional Plant Iris postii. Molecules 2021, 26, 264. https://doi.org/10.3390/ molecules26020264

Academic Editor: Natalizia Miceli Received: 11 December 2020 Accepted: 1 January 2021 Published: 7 January 2021

Publisher's Note: MDPI stays neutral with regard to jurisdictional clai$\mathrm{ms}$ in published maps and institutional affiliations.

Copyright: (C) 2021 by the authors. Licensee MDPI, Basel, Switzerland. This article is an open access article distributed under the terms and conditions of the Creative Commons Attribution (CC BY) license (https:// creativecommons.org/licenses/by/ $4.0 /)$.

\begin{abstract}
A dozen Iris species (Iridaceae) are considered traditional remedies in Kurdistan, especially for treating inflammations. Phytochemical studies are still scarce. The information reported in the literature about Iris species growing in Kurdistan has been summarized in the first part of this paper, although, except for Iris persica, investigations have been performed on vegetal samples collected in countries different from Kurdistan. In the second part of the work, we have investigated, for the first time, the contents of the methanolic extracts of Iris postii aerial parts and rhizomes that were collected in Kurdistan. Both extracts exhibited a significant dose-dependent free radical scavenging and total antioxidant activities, comparable to those of ascorbic acid. Medium-pressure liquid chromatographic separations of the two extracts afforded L-tryptophan, androsin, isovitexin, swertisin, and 2"-O- $\alpha$-L-rhamnopyranosyl swertisin from the aerial parts, whereas $\varepsilon$-viniferin, transresveratrol 3,4'-O-di- $\beta$-D-glucopyranoside, and isotectorigenin were isolated from the rhizomes. This is the first finding of the last three metabolites from an Iris species. The various remarkable biological activities of isolated compounds scientifically sustain the traditional use of $I$. postii as a medicinal plant.
\end{abstract}

Keywords: phenolics; terpenoids; isoflavones; swertisin 6-C-glycosides; resveratrol 3,4'-O-diglucoside; Iris postii; antioxidant activity; Kurdish medicinal plants

\section{Introduction}

Traditional medicines still hold an important role among health care practices of many countries, including Arab countries and Iraqi Kurdistan [1]. A Neanderthal burial discovered at Shanidar cave (number IV in the series of skeletons) in northern Iraq, dated approximately 60,000 years ago [2], is evidence that herbal medicine has probably been practiced in the mountains and plains of Kurdistan since the dawn of civilization. Indeed, a well-organized form of medicine, which made intense uses of plant-derived drugs, remedies, potions and oils, can be traced back in Iraq to the Sumerian period (3000-1970 B.C.) and then to the Babylonian and Assyrian periods (1970-539 B.C). Later, this knowledge 
was translated and enriched by Arab physicians during the Abbasid period (500-1038 A.D). Still today, the majority of the approximately 1500 plants used in Iraq are appreciated for their medicinal and aromatic properties. Most medicinal plants are collected from their wild habitats, but some are also cultivated [3].

Medicinal herbs growing in Iraqi Kurdistan are especially used by people living in the villages on the mountains and in the rural areas; however, sellers of natural medicinal products (Figure 1) are also present in the bazaars of the main towns, such as Erbil and Sulaymaniya $[4,5]$.

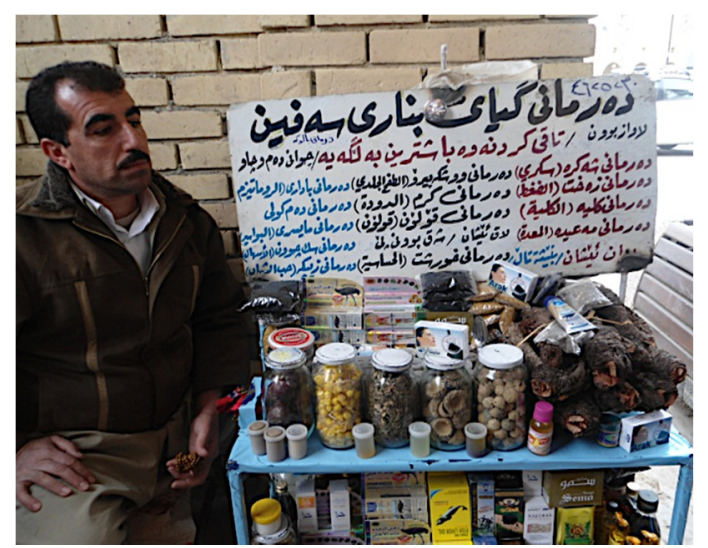

Figure 1. A Kurdish seller of traditional remedies (photo taken by H.I.M.A.).

Despite the wide use of herbal remedies, phytochemical studies on Kurdistan medicinal plants are still in their infancy and only a few papers have been published so far that describe the structures and bioactivities of isolated metabolites. As part of our ongoing project on scientific validation of Kurdistan traditional plants, we directed our attention toward the genus Iris. This large genus of the family Iridaceae (Angiosperms) contains about 260-300 species [6,7] of perennial plants growing from creeping rhizomes (rhizomatous irises) or, in drier climates, from bulbs (bulbous irises). The showy flowers are characterized by a violet-like scent. The plants grow in temperate regions across the Northern Hemisphere, from Eurasia to North America [8]. Many Iris species are ornamental plants; however, they are also used in various traditional medicines for the treatment of inflammations, cancer, bacterial and viral infections, and other diseases. Extensive phytochemical investigations of the genus have led to the isolation of different isoprenoids, flavonoids, isoflavonoids and their glycosides, xanthones, quinones, and stilbene glycosides, among others [8,9]. On the other hand, isolated bioactive compounds have shown antibacterial, anti-neoplastic, antioxidant, cytotoxic, anti-plasmodial, molluscicidal, anti-inflammatory, phytoestrogenic and antituberculosis properties [9]. Moreover, an essence called "orris butter" and an absolute essential oil with the scent of the flowers are derived from the bulbs of some Iris, e.g., I. florentina and I. germanica; they are used in the manufacture of luxury expensive perfumes, such as Chanel No. 19 (1970) and So pretty by Cartier (1995) [10].

Twelve species of Iris are reported to grow in Iraq; in the Kurdistan region, they occur especially on mountainous regions, such as Halgurd Mountain (Choman) and Korek Mountain (Rawanduz). These plants include Iris aucheri (Baker) Sealy, I. barnumiae Baker et Foster, I. caucasica Hoffm., I. gatesii Foster, I. germanica L., I. heylandiana Boiss. et Reut. ex Boiss., I. hymenospatha B. Mathew et Wendelbo, I. masia Dykes, I. persica L., I. postii Mouterde, I. pseudocaucasica Grossh., and I. reticulata M. Bieb. [11]. Of these species only I. germanica L. and I. persica L. have been investigated phytochemically. I. persica has been investigated by a Kurdish research group [12,13]; instead, due to the wide geographical distribution and economic importance, I. germanica has been subjected to several investigations in countries different from Kurdistan. The results of these investigations have been summarized in the first part of this paper. The phytochemical literature reported in Scifinder and Google Scholar databases up to August 2020 has been reviewed. In the second part of this paper, 
we describe the results of our phytochemical investigation of non-volatile secondary metabolites isolated from the aerial parts and rhizomes of Iris postii Mouterdi.

\section{Results and Discussion}

\subsection{Literature Data about Iris germanica and Iris persica}

\subsubsection{Iris germanica}

Iris germanica L. is probably the most thoroughly investigated Iris species. Rhizomes have been traditionally used for various oral and topical applications, e.g., sores, freckles [14], and to relieve teething-associated pain [15]. Root decoctions of the plant have been commonly applied as antispasmodic, emmenagogue, diuretic, anti-insomnia, and cathartic agents [16]. They decrease smooth muscle activity in vivo and show anti-serotonin effects [17]. Extracts of I. germanica showed cytotoxic [18,19], antioxidant [20-22], antimutagenic [22], antifungal [23], antimicrobial [24-26], anti-inflammatory [24,27], antibiofilm [28], antiulcer [29], hypolipidemic [30], molluscicidal [31], and amyloid $\beta$ (A $\beta$ ) induced memory impairment activities [32]. The application of rhizomes in both traditional and modern medicine has been mainly based on the presence of isoflavones and essential oils in the extracts.

\section{Isoflavonoids}

Isoflavonoids are mainly accumulate in the rhizomes and form the largest group of flavonoids isolated from I. germanica. Their structures (1-48) are shown in Figure 2, whereas the reported biological activities are shown in Table 1.

Iris isoflavonoids include germanaism A (1) [15,33,34], B (2) [15,17,33,34], C (3) [17], D (4) [17], E (5) [15,17], F (6) [17], G (7) [17], and H (8) [34], tectoridin (9) [35,36], iridin (10) $[15,24,33,35,37-40]$, iridin A (11) [40], and S (12) [38,40,41], iristectorin A (13) [39], irisolidone-7-O- $\beta$-D-glucopyranoside (14) $[15,37,42], 5,3^{\prime}$-dihydroxy-4', $5^{\prime}$-dimethoxyisoflavone 7-O-glucoside (15) [37], homotectoridin (16) [36], irilone (17) [14,15,24,34,38,40,42-45], irilone $4^{\prime}$-methyl ether (18) $[14,25,38,40]$, irilone 4'-O- $\beta$-D-glucopyranoside (19) $[15,24,33,34,38,40]$, irilone 4'-O-[ $\beta$-D-glucopyranosyl $(1 \rightarrow 6) \beta$-D-glucopyranoside] (20) [15], 8-hydroxyirilone (21) [38], 8-hydroxyirilone 5-methyl ether (22) [38], iriflogenin (23) [15,34,42,44], iriflogenin $4^{\prime}$-O-[ $\beta$-D-glucopyranosyl-( $\left.1 \rightarrow 6\right)-\beta$-D-glucopyranoside] (24) [15], irifloside (25) [15,34], irisflorentin (26) [15,44,45], dichotomitin (27) [15,37], irisolone (nigricin) (28) [14,15,23,34,44-46], nigricanin (iriskashmirianin) (29) [42,44], iriskashmirianin A (30) [34], 3'-O-metyliriskumaonin (iriskumaonin methyl ether) (31) [15,34,44,45], genistein (32) [35], 5,7-dihydroxy-3-(3'hydroxy-4', $5^{\prime}$-dimethoxy)-8-methoxy-4H-1-benzopyran-4-one (33) [14], muningin (34) [35], tectorigenin (35) [14,35], 7-O-methyl-tectorigenin-4'-O-[ $\beta$-D-glucopyranosyl- $(1 \rightarrow 6)-\beta$-Dglucopyranoside] (36) [15], irigenin (37) [14,15,24,25,35,37-40,42,44,45], irigenin $S(38)[24,38,40]$, irilin A (39) [31], B (40) [31], and D (41) [35], irisolidone (42) [15,23,24,37,38,40,42-46], iristectorigenin A (43) [14,39,44,45], 5,7-dihydroxy-3-(3'-methoxy-4'-hydroxyphenyl)-6methoxy-4H-1-benzopyran-4-one (44) [14,45], iristectorigenin B (45) [35], 5,7,3'-trihydroxy$6,4^{\prime}$-dimethoxyisoflavone-7-O-[ $\beta$-D-glucopyranosyl-( $\left.1 \rightarrow 6\right)$ - $\beta$-D-glucopyranoside] (46) [15], 5,7,8-trihydroxy-3-(4-methoxyphenyl)-2-methyl-4H-chromen-4-one (47) [47] and 6,7,-dihydroxy3-(4-methoxyphenyl)-2-methyl-4H-chromen-4-one (48) [47]. Iris isoflavanoid structures can be collected in five different groups, depending on whether they contain: (A) a methylenedioxy group at C-6 and C-7 and an oxygenated group at C-4'; (B) an $\mathrm{OH}$ group at $\mathrm{C}-5$ and a D-glucopyranosyl unit at 7-O; (C) different oxygenated functions but neither a methylenedioxy group nor a 7-O-D-glucopyranosyloxy unit; (D) a 2'-OH-group; (E) a methyl group attached to C-2. Group A includes 4'-O- mono-, di-, and triglycosides and one $3^{\prime}$-O-monoglucoside; group $\mathrm{B}$ contains only 7-O-monoglucosides; group $\mathrm{C}$ contains only 7-O- or 4'-O-diglycosides, while no sugar residue occurs in isoflavonoids of groups $\mathrm{D}$ and E. D-Glucopyranose is the only sugar present in mono- and diglucosides, whereas the only known triglycoside (6) contains an additional L-rhamnopyranosyl moiety. Diglucosides are $\beta$-D-glucopyranosyl-( $1 \rightarrow 6)-\beta$-D-glucopyranosyl derivatives, whereas triglycoside 6 is characterized by a $\beta$-D-glucopyranosyl-( $1 \rightarrow 2)$-rutinosyl unit. 

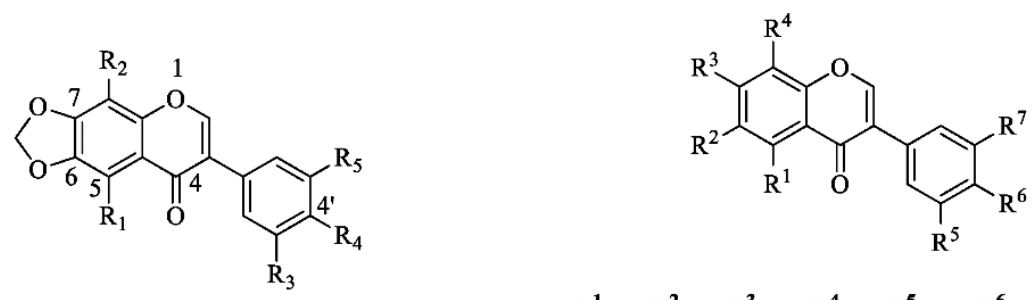

\begin{tabular}{|c|c|c|c|c|c|}
\hline & $\mathbf{R}^{1}$ & $\mathbf{R}^{2}$ & $\mathbf{R}^{3}$ & $\mathbf{R}^{4}$ & $\mathbf{R}^{5}$ \\
\hline 1 & $\mathrm{OMe}$ & $\mathrm{H}$ & $\mathrm{OMe}$ & $\mathrm{S}_{1}$ & $\mathrm{H}$ \\
\hline 2 & $\mathrm{OMe}$ & $\mathrm{H}$ & $\mathrm{H}$ & $S_{1}$ & $\mathrm{H}$ \\
\hline 5 & $\mathrm{OMe}$ & $\mathrm{H}$ & $\mathrm{H}$ & $\mathrm{S}_{2}$ & $\mathrm{H}$ \\
\hline 6 & $\mathrm{OMe}$ & $\mathrm{H}$ & $\mathrm{H}$ & $\mathrm{S}_{3}$ & $\mathrm{H}$ \\
\hline 7 & $\mathrm{OMe}$ & $\mathrm{H}$ & $\mathrm{S}_{1}$ & $\mathrm{~S}_{4}$ & $\mathrm{H}$ \\
\hline 8 & $\mathrm{OH}$ & $\mathrm{H}$ & $\mathrm{OH}$ & $\mathrm{S}_{1}$ & $\mathrm{H}$ \\
\hline 17 & $\mathrm{OH}$ & $\mathrm{H}$ & $\mathrm{H}$ & $\mathrm{OH}$ & $\mathrm{H}$ \\
\hline 18 & $\mathrm{OH}$ & $\mathrm{H}$ & $\mathrm{H}$ & $\mathrm{OMe}$ & $\mathrm{H}$ \\
\hline 19 & $\mathrm{OH}$ & $\mathrm{H}$ & $\mathrm{H}$ & $\mathrm{S}_{1}$ & $\mathrm{H}$ \\
\hline 20 & $\mathrm{OH}$ & $\mathrm{H}$ & $\mathrm{H}$ & $\mathrm{S}_{2}$ & $\mathrm{H}$ \\
\hline 21 & $\mathrm{OH}$ & $\mathrm{OH}$ & $\mathbf{H}$ & $\mathrm{OH}$ & $\mathrm{H}$ \\
\hline 22 & $\mathrm{OMe}$ & $\mathrm{OH}$ & $\mathrm{H}$ & $\mathrm{OH}$ & $\mathrm{H}$ \\
\hline 23 & $\mathrm{OH}$ & $\mathrm{H}$ & $\mathrm{OMe}$ & $\mathrm{OH}$ & $\mathrm{H}$ \\
\hline 24 & $\mathrm{OH}$ & $\mathrm{H}$ & $\mathrm{OMe}$ & $\mathrm{S}_{2}$ & $\mathbf{H}$ \\
\hline 25 & $\mathrm{OH}$ & $\mathrm{H}$ & $\mathrm{OMe}$ & $\mathrm{S}_{1}$ & $\mathrm{H}$ \\
\hline 26 & $\mathrm{OMe}$ & $\mathrm{H}$ & $\mathrm{OMe}$ & $\mathrm{OMe}$ & $\mathrm{OMe}$ \\
\hline 27 & $\mathrm{OH}$ & $\mathrm{H}$ & $\mathrm{OH}$ & $\mathrm{OMe}$ & $\mathrm{OMe}$ \\
\hline 28 & $\mathrm{OMe}$ & $\mathrm{H}$ & $\mathrm{H}$ & $\mathrm{OH}$ & $\mathrm{H}$ \\
\hline 29 & $\mathrm{OMe}$ & $\mathrm{H}$ & $\mathrm{OMe}$ & $\mathrm{OH}$ & $\mathrm{H}$ \\
\hline 30 & $\mathrm{OMe}$ & $\mathrm{H}$ & $\mathrm{OH}$ & $\mathrm{OH}$ & $\mathrm{H}$ \\
\hline 31 & $\mathrm{OMe}$ & $\mathrm{H}$ & $\mathrm{OMe}$ & $\mathrm{OMe}$ & $\mathrm{H}$ \\
\hline
\end{tabular}

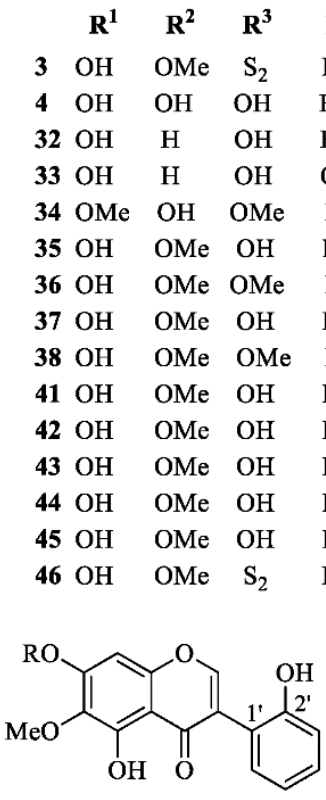

$39 \mathrm{R}=\mathrm{Me}$

$40 \mathrm{R}=\mathrm{H}$
$\begin{array}{llll}\mathbf{R}^{4} & \mathbf{R}^{5} & \mathbf{R}^{6} & \mathbf{R}^{7}\end{array}$ $\mathrm{H} \quad \mathrm{OH}$ OMe OMe $\begin{array}{llll}H & \mathrm{H} & \mathrm{S}_{2} & \mathrm{H}\end{array}$ $\begin{array}{llll}\mathrm{H} & \mathrm{H} & \mathrm{OH} & \mathrm{H}\end{array}$ $\mathrm{OMe} \mathrm{OH}$ OMe $\mathrm{OMe}$ $\mathrm{H} \quad \mathrm{H} \quad \mathrm{OH} \quad \mathrm{H}$ $\begin{array}{llll}\mathrm{H} & \mathrm{H} & \mathrm{OH} & \mathrm{H}\end{array}$ $\begin{array}{llll}\mathrm{H} & \mathrm{S}_{2} & \mathrm{H}\end{array}$ $\mathrm{OH} \mathrm{OMe} \mathrm{OMe}$ $\mathrm{OH} \mathrm{OMe} \mathrm{OMe}$ $\mathrm{OH} \mathrm{OH} \quad \mathrm{H}$ $\mathrm{H} \quad \mathrm{OMe} \mathrm{H}$ $\mathrm{OH} \mathrm{OMe} \mathrm{H}$ OMe $\mathrm{OH} \quad \mathrm{H}$ $\mathrm{OMe} \mathrm{OH} \mathrm{OMe}$ $\mathrm{OH} \mathrm{OMe} \mathrm{H}$<smiles>[R]c1c([R])c([R])c2c(=O)c(-c3ccc(OC)cc3)c(C)oc2c1[R]</smiles>

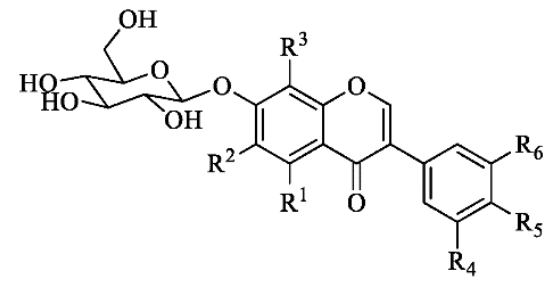

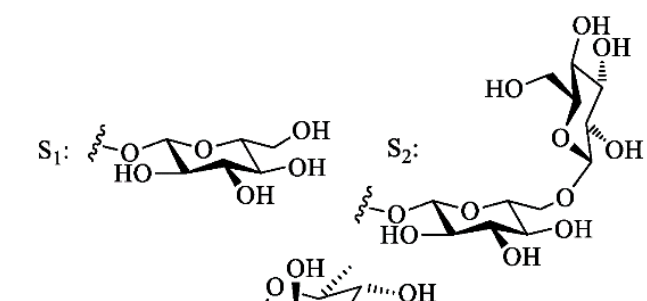
$\mathrm{O} \mathrm{OH}^{\mathrm{H}}$

$\begin{array}{cccccc}\mathbf{R}^{1} & \mathbf{R}^{2} & \mathbf{R}^{3} & \mathbf{R}^{4} & \mathbf{R}^{5} & \mathbf{R}^{6} \\ \mathrm{OH} & \mathrm{OMe} & \mathrm{H} & \mathrm{H} & \mathrm{OH} & \mathrm{H}\end{array}$

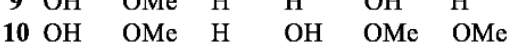
$11 \mathrm{OH} \quad \mathrm{OMe}$ OH $\mathrm{OH}$ OMe $\mathrm{OMe}$

$12 \mathrm{OH}$ OMe $\mathrm{H}$ OMe OMe OMe $13 \mathrm{OH}$ OMe $\mathrm{H} \quad \mathrm{H} \quad \mathrm{OMe} \mathrm{OH}$ $14 \mathrm{OH}$ OMe $\mathrm{H} \quad \mathrm{H} \quad \mathrm{OMe} \mathrm{H}$

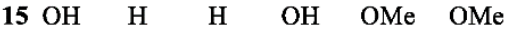
$16 \mathrm{OH} H \mathrm{OMe} \mathrm{OMe} \mathrm{OH} \mathrm{H}$

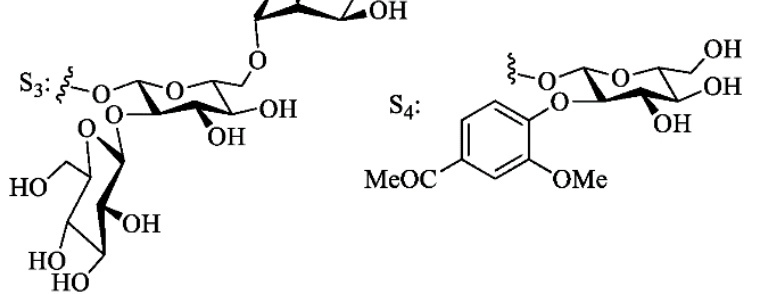

Figure 2. Characteristic isoflavonoids isolated from Iris germanica. 
Table 1. Biological activities reported for the isoflavonoids isolated from Iris germanica.

\begin{tabular}{|c|c|c|}
\hline Compound & Bioactivity & Reference \\
\hline Germanaism A (1) & Cytotoxic activity $\mathrm{IC}_{50}=43.9 \pm 1.5 \mu \mathrm{M}(\mathrm{MTT}) ; 4.5 \pm 0.4 \mu \mathrm{M}(\mathrm{ATP})$ & {$[34]$} \\
\hline Tectoridin (9) & $\begin{array}{l}\text { Free-radical scavenger, antioxidant, anti-inflammatory, antiproliferative, } \\
\text { oestrogenic, anti-alcohol injury, hepatoprotective effects }\end{array}$ & [48] \\
\hline Iridin (10) & Potent anti-inflammatory effects (induced paw edema test) & [24] \\
\hline Iridin A (11) & $\begin{array}{l}\text { High antioxidant activity; } \\
\alpha \text {-amylase inhibitory activity }\end{array}$ & {$[38,40]$} \\
\hline Irisolidone 7-O- $\beta$-D-glucopyranoside (14) & CyP1A inhibitor; QR inhibitor; DPPH scavenger & \\
\hline Irilone (17) & $\begin{array}{c}\text { Cytotoxic activity } \mathrm{IC}_{50}=47.7 \pm 3.5 \mu \mathrm{M}(\mathrm{MTT}), 17.7 \pm 1.4 \mu \mathrm{M}(\mathrm{ATP}) ; \\
\text { potent anti-inflammatory effects (induced paw edema test): } \\
\text { high antioxidant activity; } \\
\alpha \text {-amylase inhibitory activity; } \\
\text { potent inhibitor of cytochrome P450 1A activity }\left(\mathrm{IC}_{50}=0.3 \pm 0.1 \mu \mathrm{M}\right) ; \\
\text { immunomodulatory activity; CyP1A inhibitor; moderate QR inhibitor; } \\
\text { DPPH scavenger }\end{array}$ & $\begin{array}{l}{[34]} \\
{[24]} \\
{[38,40]} \\
{[42]} \\
{[43]}\end{array}$ \\
\hline Irilone $4^{\prime}$-O- $\beta$-D-glucopyranoside (19) & Potent anti-inflammatory effects (induced paw edema test) & [24] \\
\hline 8-Hydroxyirilone (21) & High antioxidant activity; $\alpha$-amylase inhibitory activity & {$[38,40]$} \\
\hline 8-Hydroxyirilone 5-methyl ether (22) & $\begin{array}{l}\text { High antioxidant activity; } \\
\alpha \text {-amylase inhibitory activity }\end{array}$ & {$[38,40]$} \\
\hline Iriflogenin (23) & $\begin{array}{l}\text { Potent inhibitor of cytochrome P450 1A activity }\left(\mathrm{IC}_{50}=1.4 \pm 0.6 \mu \mathrm{M}\right) \text {; } \\
\text { CyP1A inhibitor; weak DPPH scavenger }\end{array}$ & [42] \\
\hline Irifloside (25) & Cytotoxic activity $\mathrm{IC}_{50}=21.5 \pm 4.4 \mu \mathrm{M}(\mathrm{MTT}) ; 19.4 \pm 1.3 \mu \mathrm{M}(\mathrm{ATP})$ & [34] \\
\hline Irisolone (nigricin) (28) & High anti-inflammatory activity & [14] \\
\hline Nigricanin (iriskashmirianin) (29) & CyP1A inhibitor; moderate QR inhibitor; weak DPPH scavenger & [42] \\
\hline Iriskashmirianin A (30) & Cytotoxic activity $\mathrm{IC}_{50}=20.9 \pm 2.7 \mu \mathrm{M}(\mathrm{MTT}) ; 4.3 \pm 0.9 \mu \mathrm{M}(\mathrm{ATP})$ & [34] \\
\hline $\begin{array}{l}\text { 5,7-Dihydroxy-3-(3'-hydroxy-4 } 4^{\prime}, 5^{\prime}- \\
\text { dimethoxy)-8-methoxy- } 4 \mathrm{H}-1- \\
\text { benzopyran-4-one } \\
\text { (33) }\end{array}$ & Significant anti-inflammatory activity & [14] \\
\hline Tectorigenin (35) & $\begin{array}{c}\text { Antifungal, free radical scavenger, antioxidant, anti-inflammatory, } \\
\text { anti-angiogenic, antiproliferative, antineoplastic, hypoglycaemic, } \\
\text { oestrogenic, hepatoprotectiv, antithrombotic, cardiovascular, anti-alcohol } \\
\text { injury activities; } \\
\text { in patented pharmaceutical compositions for the treatment of } \\
\text { hormone-related diseases }\end{array}$ & {$[48,49]$} \\
\hline Irigenin (37) & $\begin{array}{c}\text { Potent anti-inflammatory effects (induced paw edema test and inhibition } \\
\text { against superoxide); } \alpha \text {-amylase inhibitory activity; potent inhibitor of } \\
\left.\text { cytochrome P450 1A activity ( } \mathrm{IC}_{50}=1.2 \pm 0.3 \mu \mathrm{M}\right) \text {; CyP1A inhibitor; } \\
\text { moderate QR inhibitor, DPPH scavenger }\end{array}$ & $\begin{array}{c}{[14,24]} \\
{[38,40]} \\
{[42]}\end{array}$ \\
\hline Irigenin S (38) & Potent anti-inflammatory effects (induced paw edema test) & [24] \\
\hline Irisolidone (42) & $\begin{array}{c}\text { Potent anti-inflammatory effects (induced paw edema test); } \\
\alpha \text {-amylase inhibitory activity; immunomodulatory activity; CyP1A } \\
\text { inhibitor; QR inhibitor; DPPH scavenger; antiproliferative activity } \\
\text { against amelanotic melanoma and large lung carcinoma cells; antioxidant } \\
\text { properties }\end{array}$ & $\begin{array}{c}{[24]} \\
{[38,40]} \\
{[43]} \\
{[50]} \\
{[51]}\end{array}$ \\
\hline Iristectorigenin A (43) & Weak anti-inflammatory activity & [14] \\
\hline
\end{tabular}


Table 1. Cont.

\begin{tabular}{ccc}
\hline Compound & Bioactivity & Reference \\
\hline Isoflavone (44) & Moderate anti-inflammatory activity & [14] \\
\hline $\begin{array}{c}\text { 5,7,8-Trihydroxy-3-(4-methoxyphenyl)-2- } \\
\text { methyl-4H-chromen-4-one } \\
(47)\end{array}$ & $\begin{array}{c}\text { Significant inhibition of TRAP in NF-kB ligand-induced osteoclastic } \\
\text { RAW 264.7 cells (66.67 } \pm 2.71 \%)\end{array}$ \\
\hline $\begin{array}{c}\text { 6,7-Dihydroxy-3-(4-methoxyphenyl)-2- } \\
\text { methyl-4H-chromen-4-one }\end{array}$ & $\begin{array}{c}\text { Significant inhibition of TRAP in NF-kB ligand-induced osteoclastic } \\
(48)\end{array}$ & RAW 264.7 cells $(57.32 \pm 2.46 \%)$ \\
[47]
\end{tabular}

\section{Other Flavonoids}

Compared to isoflavonoids, representative compounds of other flavonoid classes occur less frequently in the extracts of I. germanica. Isolated flavanones (Figure 3) are naringenin (49) [35] and 5,7,2'-trihydroxy-6-methoxyflavanone (50) [31], whereas flavanonols include dihydroquercetin-7,3' -dimethylether (51) [45], dihydroquercetin-7,4'-dimethylether (52) [35], and dihydroquercetin-7,3'-dimethylether-5-O- $\beta$-D-glucopyranoside (53) [35]. Flavones are represented by the $O$-glucoside cirsiliol-4'-O-glucopyranoside (54) [35] and the $C$-diglucoside PID (55) [52,53]. Flavonols and flavan-3-ols include ombuin (56) [35] and 5,2'-dihydroxy-3-methoxy-6,7-methylenedioxyflavone (57) [31], and (+)-(2R,3S)-catechin (58) [22], respectively. The anthocyanin delphanin (delphinidin-3-(4-p-coumaroylrhamnosyl$(1 \rightarrow 6)$-glucoside)-5-glucoside) (59) was isolated from flowers of I. germanica [54].<smiles>[R]c1ccc(C2CC(=O)c3c(cc(O)c([R])c3O)O2)c([R])c1</smiles><smiles>[R10]Oc1ccc(-c2oc3cc(OC)cc(OC)c3c(=O)c2O)cc1OC</smiles>

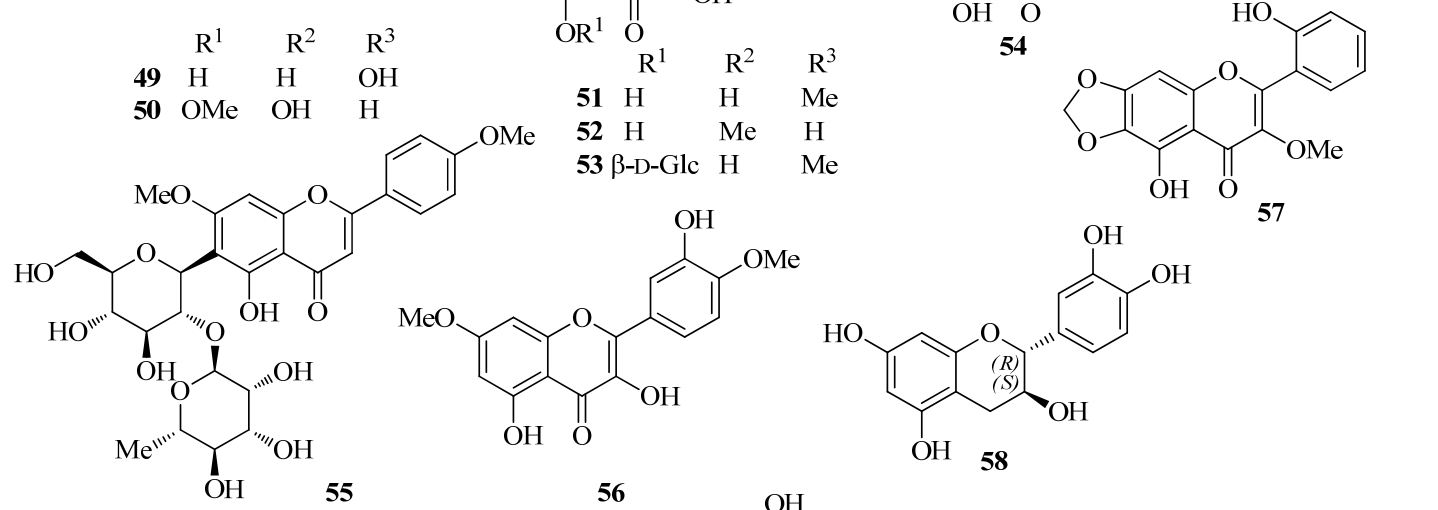
$\begin{array}{llll}\mathrm{OR}^{1} & \mathrm{O} & & \\ \mathrm{R}^{1} & \mathrm{R}^{2} & \mathrm{R}^{3}\end{array}$ $\begin{array}{llll}51 & \mathrm{H} & \mathrm{H} & \mathrm{Me}\end{array}$ $\mathbf{5 2} \mathrm{H} \quad \mathrm{Me} \quad \mathrm{H}$ $53 \beta$-D-Glc $\mathrm{H}$ Me<smiles>COc1cc(OC2OC(CO)[C@@H](O)[C@H](O)C2O)c2cc(O[C@@H]3O[C@H](OC[C@@H]4O[C@@H](C)[C@@H](O)C(O)[C@H]4O)[C@@H](O)[C@H](O)[C@H]3O)c(-c3cc(O)c(O)c(O)c3)[o+]c2c1</smiles>

Figure 3. Characteristic flavonoids other than isoflavones isolated from Iris germanica.

\section{Miscellaneous Aromatic Compounds}

Other aromatic compounds (Figure 4 ) isolated from $I$. germanica include the C-glucosylxanthon mangiferin (60) [35] and irisxanthone (61) [35]; the phenol derivatives 2,4',6-trihydroxy-4methoxybenzophenone-2-O- $\beta$-D-glucoside (62) [35], 1-(2-(6'-hydroxy-2'-methylcyclohex- 
$1^{\prime}$-enyloxy)-5-methoxyphenyl)ethanone (63) [23,44], isopeonol (64) [43], acetovanillone (65) $[15,23,35,37,44,46]$, androsin (66) [35], and 3-hydroxy-5-methoxyacetophenone (67) [24]; the alkaloids 1,2,3,4-tetrahydro- $\beta$-carboline-3-carboxylic acid (68) [55] and the corresponding (S)-(-)-methyl ester [55], (1S,3R)-methyl 1-methyl-2,3,4,9-tetrahydro-1H-pyrido[3,4b]indole-3-carboxylate (69) [55], methyl (1R,3R)-1-methyl-2,3,4,9-tetrahydro-1H-pyrido[3,4b]indole-3-carboxylate (70) [55], 4-(9H- $\beta$-carbolin-1-yl)-4-oxobut-2-enoic acid methyl ester (71) [55], 2-(furan-2-yl)-5-(2,3,4-trihydroxybutyl)-1,4-diazine (crotonine) (72) [55], 3- $\beta$-Dribofuranosyluracil (uridine) [55], 6-hydroxymethyl-3-pyridinol (73) [55], and 2-amino-1Himidazo-[4,5-b]pyrazine (74) [55]; the benzoic and cinnamic acid derivatives pyroglutamic acid [35], protocatechuic acid (75) [22], chlorogenic acid (76) [22], caffeic acid (77) [22], ferulic acid (78) [22], and p-hydroxy benzoic acid [22]. Crotonine (72) showed good analgesic activity in vivo [55].<smiles>[R]c1cc2c(=O)c3c(O)c([C@@H]4O[C@H](CO)[C@@H](O)[C@H](O)[C@H]4O)c(O)cc3oc2c([R])c1O</smiles>

$\begin{array}{ccc} & \mathrm{R} 1 & \mathrm{R} 2 \\ \mathbf{6 0} & \mathrm{H} & \mathrm{OH} \\ \mathbf{6 1} & \mathrm{OMe} & \mathrm{H}\end{array}$<smiles>COc1cc(O)ccc1C(C)=O</smiles>

64<smiles>[R]Oc1ccc(C(C)=O)cc1OC</smiles>

$65 \mathrm{R}=\mathrm{H}$ $66 \mathrm{R}=\beta-\mathrm{D}-\mathrm{Glc}$<smiles>COc1cc(O)c(C(=O)c2ccc(O)cc2)c(OOC(O)C2OC3C(O)C(O)CC(O)C3(O)C(O)C2O)c1</smiles>

62<smiles>COc1ccc(OC2=C(C)CCCC2O)c(C(C)=O)c1</smiles>

63<smiles>COc1cc(O)cc(C(C)=O)c1</smiles><smiles>N#CC1Cc2c([nH]c3ccccc23)CN1</smiles>

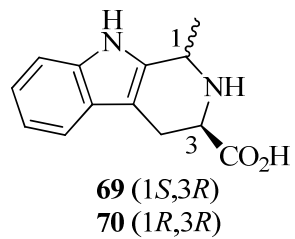<smiles>CC(=O)C=CC(=O)c1nccc2c1[nH]c1ccccc12</smiles>

71<smiles>OCC(O)C(O)Cc1cnc(-c2ccco2)cn1</smiles><smiles>OCc1ccc(O)cn1</smiles><smiles>Nc1nc2nccnc2[nH]1</smiles><smiles>O=C(O)c1ccc(O)c(O)c1</smiles><smiles>O=C(/C=C/c1ccc(O)c(O)c1)OC1CC2(O)C(=O)C(O)C1CC2(O)O</smiles><smiles>[R2]Oc1cc(/C=C/C(=O)O)ccc1O</smiles>

Figure 4. Miscellaneous aromatic compounds isolated from Iris germanica.

Terpenoids

In addition to $\alpha$ - and $\beta$-amyrin [37], the most widespread triterpenoids occurring in I. germanica are iridals (Figure 5) [56]. These bitter tasting terpenoids can be isolated in appreciable amounts from the unsaponifiable fraction of lipid extracts from the rhizomes. Characteristic features of all iridals are a multi-substituted cyclohexane ring with a long side chain at C-11 (squalene numbering), an acrolein group at C-7, and a hydroxypropyl chain at C-6. The latter two substitutions are typical fragments of a seco A-ring of triterpenoids. Appropriate labeling experiments have shown that 2,3-epoxysqualene is the precursor of the iridals and that a bicyclic intermediate is possibly formed in the biosynthetic pathway, the A ring of which is subsequently opened to give the iridal skeleton [56]. Other labeling experiments have also proved the involvement of activated methionine for the introduction of the extra methyl group at C-22 of an open-chain precursor of methylated cycloiridals and irones [56]. The large group of iridals isolated from I. germanica 
include iridal (79) [57-60], iridogermanal (80) [61], isoiridogermanal (81) [60,62,63], 16$O$-acetylisoiridogermanal (82) [59,60,62], irisgermanical A (83) [60,62], irisgermanical B (84) [60,62], irisgermanical C (85) [60,62,63], iriflorental (86) [59,60,62,63], $\alpha$-irigermanal (87) [59-63], iripallidal (88) [60,62,63], $\gamma$-irigermanal (89) [29,59-63], compound 90 [63], $\alpha$-dehydroirigermanal (91) [60,62,63], irigermanone (92) [63], iridobelamal A (93) [63], iristectorone K (94) [64], 29-acetoxyspiroiridal (95) [59]. Compound 79 showed potent antimalarial activity both in vitro and in vivo [57]. Compounds 79, 82, 86, 87, 89, and 95 exhibited significant cytotoxicity against K562 leukema and A2780 ovarian cell lines [59]. Compounds 86, 88 and 89 showed potent piscicidal activities at a concentration of less than $1 \mu \mathrm{g} / \mathrm{mL}$ of median tolerance limit (TLm) value [60,62], and compound 89 exhibited significant antiulcer activity $[29,65]$.

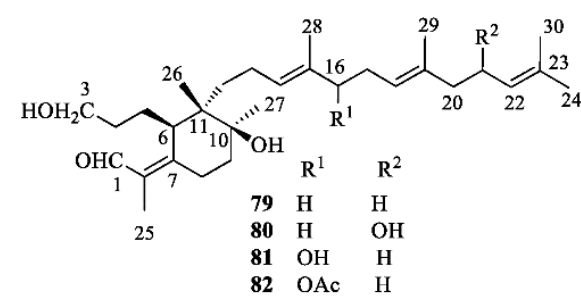

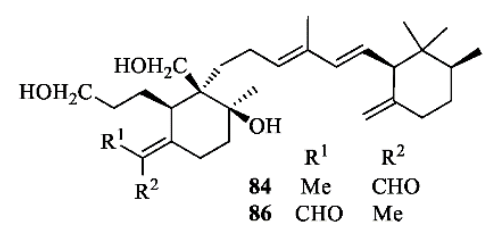

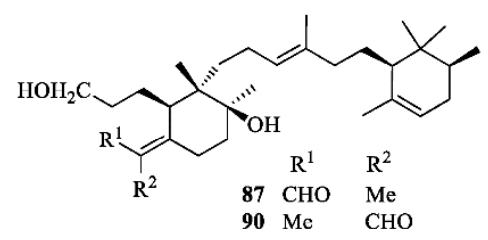

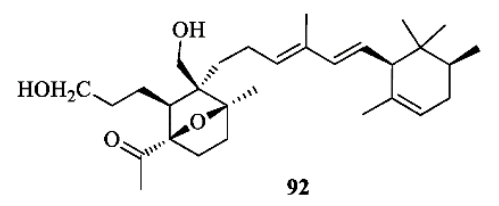

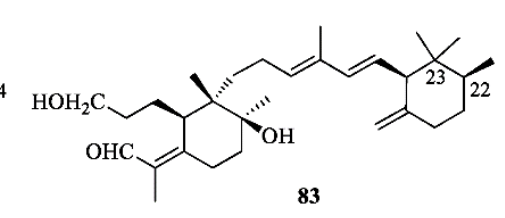

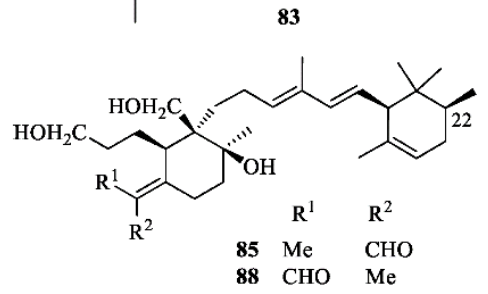<smiles>C=C1CCC(C)C(C)(C)C1CCC(C)=CCC1(C)C(C)CCC(=C(C)COCC)C1CCCO</smiles>

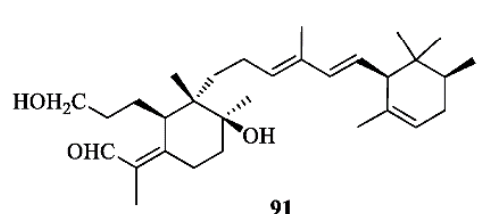

91

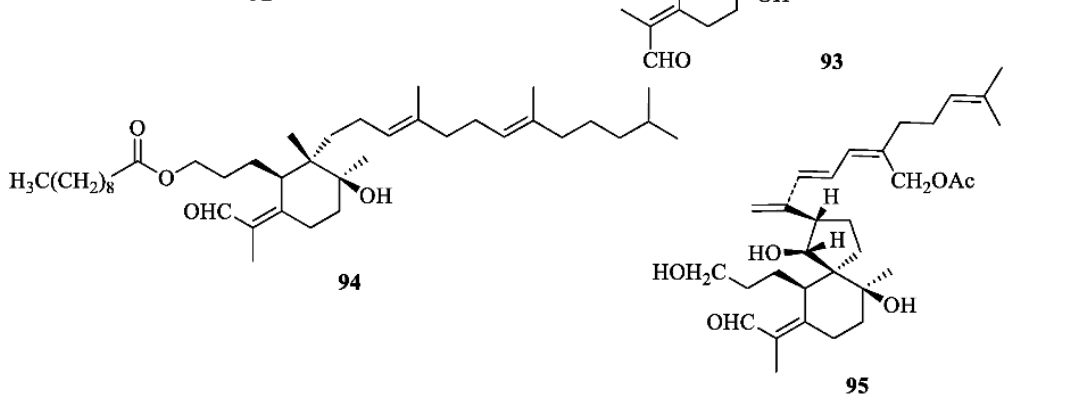

Figure 5. Iridals isolated from Iris germanica.

$\alpha-(96), \beta-(97)$, and $\gamma$-Irone (98) (Figure 6) are the odoriferous principle of iris oils. It is well known that freshly harvested iris rhizomes do not contain irones, but their triterpenoid precursors iridals (Figure 5). According to the traditional procedure, decorticated rhizomes of some Iris species (e.g., I. germanica, I. pallida, I. florentina) are kept in a dry and aerated environment for 2-3 years, then powdered, incubated with diluted sulphuric acid, and steam-distilled to provide the precious "orris butter". The mechanism of the oxidative degradation affording irones from iridals is still poorly understood. The traditional process 
is long, troublesome and low yielding; hence, the high cost of the essence (butter). Purification of the essence eliminates the fatty acids and yields the absolute, which is sold at several thousands of dollars per kilogram [10]. It has been established that the distribution of irone isomers and enantiomers in different qualities of iris oils depends upon the botanical species of the plant [44]. Thus, the average composition of an iris butter prepared from Iris germanica is the following: $0.91 \%$ of $(+)$-trans- $\alpha$-irone (ee $=96 \%,(+)-96 a), 61.48 \%$ of (-)-cis- $\alpha$-irone (ee $=82 \%,(-)-96 b), 0.71 \%$ of $\beta$-irone $(97)$ and $37.60 \%$ of $(-)$-cis- $\gamma$-irone (ee

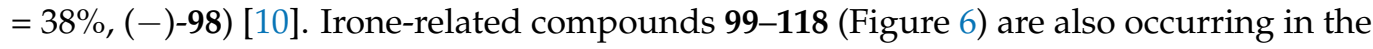
essential oil [66].

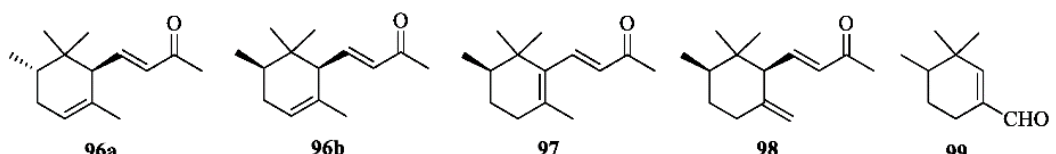

96a

96b

97

99<smiles>CC1=CCC(C)C(C)(C)C1=O</smiles>

100<smiles>CC1=CC(=O)C(C)(C)C(C)(C)C1=O</smiles>

101<smiles>CC1=CCC(C)C(C)(C)C1(C)C</smiles>

102<smiles>CC1=C(C)C(C)C(C)(C)C1</smiles>

103

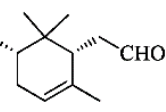

104<smiles>C=C1CCC(C)C(C)(C)C1(C)CC=O</smiles>

105<smiles>CC1=CCC(C)C(C)C1(C)/C=C/CO</smiles><smiles>CC(=O)CCC1C(C)=CC[C@H](C)C1(C)C</smiles><smiles>CC(=O)CCC1(C)C(C)=CCC(C)C1(C)C</smiles><smiles>CC(=O)CCC1=C(C)CCC(C)C1(C)C</smiles>

106

107

108

109<smiles>CC(=O)[C@H]1O[C@H]1[C@H]1C(C)=CC[C@H](C)C1(C)C</smiles><smiles>CC(=O)/C=C/C1=C(C=O)CCC(C)C1(C)C</smiles><smiles>CCC(=O)C=CC1C(C)C=CC[C@H](C)C1(C)C</smiles>

112<smiles>CCC(=O)/C=C/C1CCC(C)C1(C)C</smiles>

113

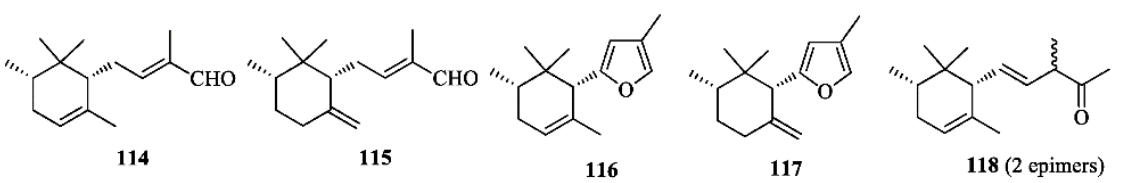

Figure 6. Irones and irone-related compounds isolated from Iris germanica.

Steroids and Miscellaneous Compounds

Common sterols isolated from I. germanica include: cholesterol [67], campesterol [67], sitosterol [37,67], $\beta$-sitosterol [35], daucosterol [35], stigmasterol [24,67], and stigmasterol$3-O-\beta$-D-glucopyranoside [24]. Compounds of different biogenetic origin (Figure 7) include iriside A (96) [24], irisamides A (97) [41], irisamides B (98) [41], 6,6-ditetradecyl-6,7dihydrooxepin-2(3H)-one (102) [23], 2-acetoxy-3,6-dimethoxy-1,4-benzoquinone (108) [23] Compounds 97 and 98 were reported to be active against L5178Y and Hela tumor cell lines [41].<smiles>OC1CC(O)C(O)CO1</smiles>

96

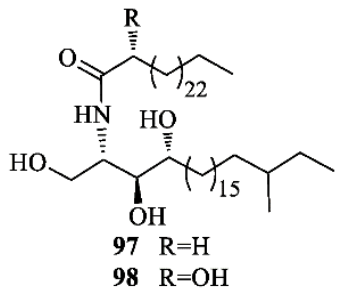

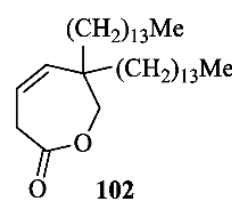

102<smiles>COC(=O)C1C(=O)C=C(OC)C(OC)C1=O</smiles>

108

Figure 7. Miscellaneous compounds isolated from Iris germanica.

\subsubsection{Iris persica}

I. persica is used to treat tumors and wound inflammation in the traditional medicine of Kurdistan [5]. Essential oils obtained by hydrodistillation of air-dried flowers, leaves, rhizomes, and fresh bulbs were investigated by GC-FID and GC-MS; moreover, the oil antifungal activities were determined [12]. The major constituents of the flower essential oil were phenylethanol $(24.8 \%)$ and furfural $(13.8 \%)$. This aldehyde was also the main 
component of the leaf and rhizome volatile fractions, with percentages of $39.0 \%$ and $22.2 \%$, respectively. Phenylacetaldehyde (37.1\%) was the main constituent of the volatile fraction from the bulbs. The oils exhibited moderate antifungal activity in vitro against strains of the human pathogenic fungi Candida albicans, Microsporum canis, and Trichophyton mentagrophytes, the plant-fungal pathogen Pyricularia oryzae, and the fungal food contaminant Aspergillus carbonarius. The highest activity was exhibited by the essential oils isolated from leaves and flowers, so that they could be considered natural antimicrobial agents.

A few known bioactive flavonoids (Figure 8) were abundant in the non-volatile extracts of the plant. Thus, the C-diglucoside flavone embinin (55) was isolated from flowers and leaves, the 6-C-glucoside flavone isovitexin (109) was isolated from flowers, the stilbenoid (-)-trans-resveratrol-3-O- $\beta$-D-glucopyranoside (110) was found in rhizomes, and the isoflavone (+)-tectorigenin (35) was isolated from bulbs [13]. In an MTT assay, embinin (55) showed a significant inhibitory activity that was higher than the well-known antitumor drug cisplatin, against MCF7, SkBr3, Ishikawa, BG-1, and A549 human tumor cells. Moreover, embinin showed a remarkable DPPH radical scavenging activity, that was comparable to that of the well-known antioxidant ascorbic acid [13].<smiles>O=c1cc(-c2ccc(O)cc2)oc2cc(O)c([C@@H]3O[C@H](CO)[C@@H](O)[C@H](O)[C@H]3O)c(O)c12</smiles>

Figure 8. Characteristic phenolic compounds isolated from Iris persica.

\subsection{Phytochemical Studies on Iris postii}

A decoction of the aerial parts of Iris postii Mouterde is used in the Iraqi folkloric medicine as a general remedy against inflammations. The plant, which is native to Middle East, grows wildly on the slopes of Mount Korek (Figure 9), a mountain located in the Erbil province not far from the Iranian border, where it was collected for this investigation.
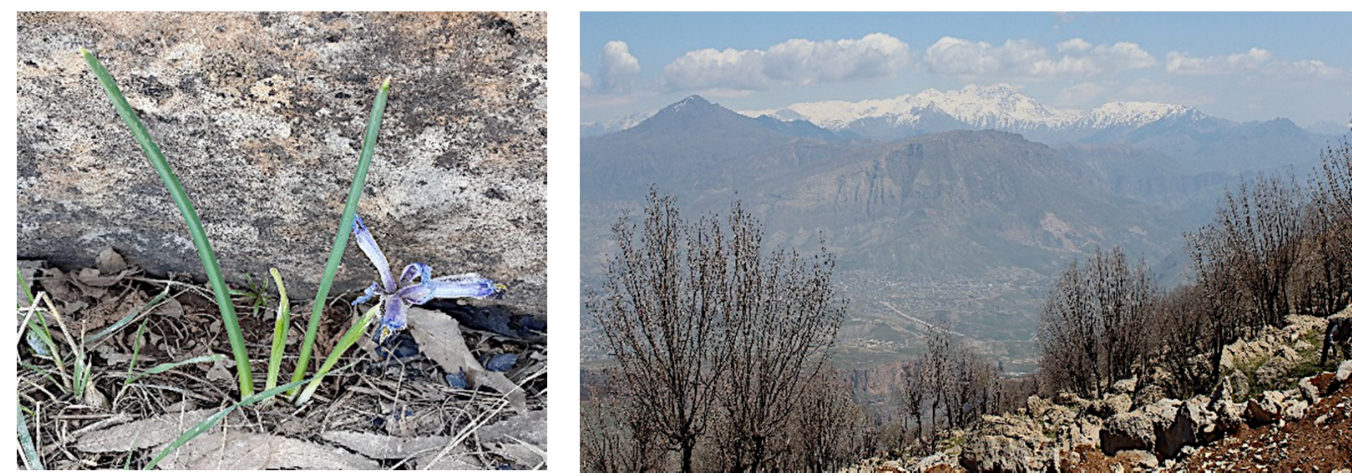

Figure 9. Iris postii and Korek mountain where the plant was collected (photos taken by H.I.M.A.).

Neither phytochemical investigations nor evaluations of biological activities have been carried out on extracts of I. postii so far. Therefore, on the assumption that the bioactivity mostly resided in polar metabolites, we decided to examine the phytochemical contents and the antioxidant properties of polar extracts of the aerial parts and rhizomes.

At first, powdered aerial parts and rhizomes were separately defatted by soaking in hexane at room temperature; most chlorophyll was also removed in this manner. Successively, each biomass was extracted with $\mathrm{MeOH}$. The yields of the residues, IPA from the aerial parts and IPR from the rhizomes, were 1.3 and $2.75 \%(w / w)$, respectively. Successively, IPA and IPR were separately partitioned between $\mathrm{H}_{2} \mathrm{O}$ and dichloromethane and 
$\mathrm{H}_{2} \mathrm{O}$ and $n$-butanol, respectively, to give fractions IPAD and IPRB, respectively. Multiple medium-pressure liquid chromatographic separations of a sample of IPAD on reversedphase (RP-18) columns afforded L-tryptophan, androsin (66), apigenin 6-C-glucoside (isovitexin) (109), swertisin (111), and 2"-O-rhamnosyl swertisin (112). Analogous chromatographic separations of a sample of IPRB gave trans- $\varepsilon$-viniferin (113), trans-resveratrol 3,4'-O-diglucoside (114), and isotectorigenin (115). The structures of isolated compounds (Figure 10) were established mainly by extensive 1D- and 2D-NMR experiments and MS spectrometry. Comparing our spectroscopic data with the pertinent literature, we found some differences between our data and those reported from different laboratories, especially for the NMR signals of swertisin (111) [68-73] and 2"-O-rhamnosylswertisin (112) [71,74]; moreover, literature data are often not consistent between each other and some spectra have been recorded in solvents different from those used in this work. Therefore, although the isolated compounds are known, the physical and spectroscopic data determined by us are reported in the Experimental section, whereas the graphics are included in the Supplementary Materials.

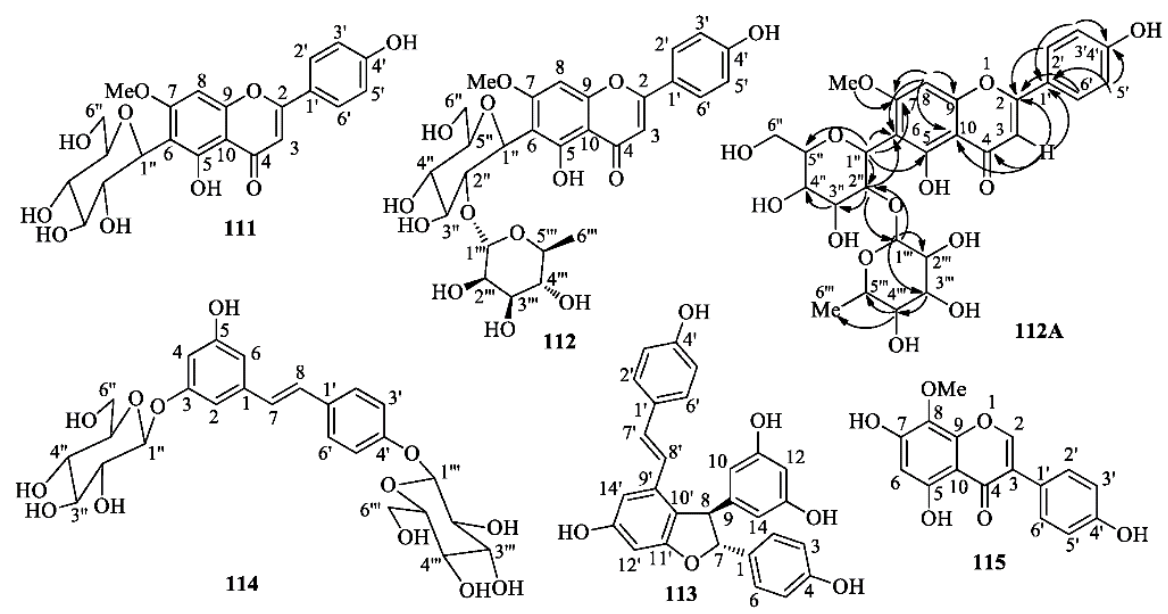

Figure 10. Structures of swertisin (111), 2"-O-rhamnosyl swertisin (112), viniferin (113), resveratrol $3,4^{\prime}$-O-di- $\beta$-D-glucopyranoside (114), isotectorigenin (115) isolated from Iris postii Mouterde; $\mathrm{H} \rightarrow \mathrm{C}$ HMBC correlations determined in the 2D-NMR spectrum of 2"-O-rhamnosyl swertisin (112A).

It is now generally accepted by scientists that excess oxidants and radicals, especially oxygen radicals, through damage and mutation of DNA and other biomolecules, play a major role in degenerative processes that may cause the insurgence and progression of inflammatory processes, cancer, cardiovascular and atherosclerotic diseases, neurodegeneration, and aging [75,76]. Antioxidants isolated from natural sources could thus become important chemotherapeutic agents in defense mechanisms against these toxic agents. Therefore, with the aim to give some scientific evidence to the traditional use of I. postii in the treatment of inflammations and in search of a new source of natural antioxidants, two simple tests were performed in vitro to determine the total antioxidant capacity (TAOC) of the crude extracts (see text) and the antiradical activity of the extracts and the isolated compounds. The TAOC values of the extracts were determined by the phosphomolybdate method (adjusted from references [77-79]), using ascorbic acid as the standard. The assay was based on the reduction of hexavalent molybdenum Mo (VI) to the pentavalent form [Mo (V)] by an antioxidant, and the formation of a green phosphate/Mo (V) complex at acidic $\mathrm{pH}$ and at high temperature. The TAOC values were expressed as $\mu \mathrm{g}$ ascorbic acid equivalent/mg extract (Table 2 ). The greater this value, the higher was the antioxidant capacity. Thus, the total methanol extract of the aerial parts (IPA) and the $n$-butanol sub-extract of the methanolic extract of the rhizomes (IPRB) exhibited the highest total antioxidant activity. Moreover, comparing the TAOC of the IPA extract with that of the dichloromethane sub-extract (IPAD), it appears that highly antioxidant compounds, likely very polar, were not adequately extracted by $\mathrm{CH}_{2} \mathrm{Cl}_{2}$. Therefore, they need further study. 
Table 2. Antiradical and antioxidant activities of extracts and compounds isolated from Iris postii.

\begin{tabular}{|c|c|c|c|c|}
\hline \multirow{2}{*}{ Sample } & \multicolumn{3}{|c|}{ DPPH Scavenging Activity } & \multirow{2}{*}{ Total Antioxidant Capacity (TAOC) } \\
\hline & $\mathrm{EC}_{50}(\mu \mathrm{g} / \mathrm{mL})$ & $\mathrm{EC}_{50}(\mu \mathrm{M} / \mathrm{L})$ & $\mathrm{AAE}^{\mathrm{a}}$ & \\
\hline Androsin (66) & $48.94 \pm 0.09$ & 149.21 & 0.48 & - \\
\hline Isovitexin (109) & $50.97 \pm 1.11$ & 117.99 & 0.46 & - \\
\hline Swertisin (111) & $37.35 \pm 0.13$ & 83.74 & 0.63 & - \\
\hline 2"-O- $\alpha$-L-Rhamnosyl swertisin (112) & $26.52 \pm 0.11$ & 44.79 & 0.89 & - \\
\hline$\varepsilon$-Viniferin (113) & $26.06 \pm 0.01$ & 57.39 & 0.90 & - \\
\hline $\begin{array}{c}\text { Trans-resveratrol } \\
3,4^{\prime} \text {-O-di- } \beta \text {-D-glucopyranoside (114) }\end{array}$ & $22.91 \pm 0.05$ & 41.50 & 1.03 & - \\
\hline Isotectorigenin (115) & $34.87 \pm 0.13$ & 116.23 & 0.67 & - \\
\hline Ascorbic acid & $23.52 \pm 0.22$ & 133.63 & 1.00 & - \\
\hline $\mathrm{IPA}^{\mathrm{c}}$ & $19.21 \pm 0.01$ & - & 1.22 & 0.39 \\
\hline IPAD $^{d}$ & $62.79 \pm 0.03$ & - & 0.37 & 0.21 \\
\hline $\mathrm{IPR}^{\mathrm{e}}$ & $46.28 \pm 0.12$ & - & 0.51 & 0.29 \\
\hline IPRB $^{f}$ & $39.11 \pm 0.10$ & - & 0.60 & 0.46 \\
\hline
\end{tabular}

${ }^{a}$ Expressed as $\mu \mathrm{g}$ ascorbic acid equivalents $/ \mu \mathrm{g}$ sample; ${ }^{\mathrm{b}}$ expressed as $\mu \mathrm{g}$ ascorbic acid equivalents $/ \mu \mathrm{g}$ extract; ${ }^{\mathrm{c}}$ methanol extract of aerial parts; ${ }^{\mathrm{d}}$ dichloromethane fraction from IPA; ${ }^{\mathrm{e}}$ methanol extract of rhizomes; ${ }^{\mathrm{f}}$ butanol fraction from IPR.

Subsequently, the free radical scavenging (FRS) activity of the isolated compounds 66, 109, 111-115, the crude extracts and the standard ascorbic acid were determined using the 2,2-diphenyl-1-picrylhydrazyl radical (DPPH) method (adjusted from references [78,79]). $\mathrm{DPPH}$ is a stable, nitrogen-centered free radical which produces violet/purple color in methanol solution and fades to shades of yellow color in the presence of a hydrogen radical/electron-donor compound. The antiradical activity was expressed as $\mathrm{EC}_{50}$ value, i.e., the concentration $(\mu \mathrm{g} / \mathrm{mL})$ of the sample required to scavenge $50 \%$ of the initial DPPH concentration and as $\mu \mathrm{g}$ ascorbic acid equivalents/ $\mu \mathrm{g}$ sample. In the case of isolated compounds, the activity was also measured as $\mathrm{EC}_{50}(\mu \mathrm{M} / \mathrm{L})$, which, in our opinion, is a more accurate measurement of the intrinsic antiradical activity of a compound. The results of the DPPH assay (Table 2) essentially confirmed those obtained by the molybdate test as far as the antioxidant activity of the extracts is concerned. On the other hand, concerning the DPPH scavenging activity of single compounds, 2"-O- $\alpha$-L-rhamnosyl- swertisin (112), $\varepsilon$-viniferin (113), and resveratrol 3,4'-O-di- $\beta$-D-glucopyranoside (114) were as effective as the standard ascorbic acid or even more efficacious. The remaining isolated compounds, androsin (66), isovitexin (109), swertisin (111), and isotectorigenin (115), were moderately active, although the EC50 values of compounds 109, 111 and 115, expressed as $\mu \mathrm{M} / \mathrm{L}$, were lower than that of ascorbic acid.

\section{Material and Methods}

\subsection{General Experimental Techniques and Procedures}

For most general experimental techniques and procedures, see reference [80]; ${ }^{1} \mathrm{H}$ NMR and ${ }^{13} \mathrm{C}$-NMR chemical shifts $(\delta, \mathrm{ppm})$ are relative to signals of residual $\mathrm{CHD} \mathrm{D}_{2} \mathrm{OD}$ in $\mathrm{CD}_{3} \mathrm{OD} \delta_{\mathrm{H}} 3.27$ (central line of a quintuplet), ${ }^{13} \mathrm{CD}_{3} \mathrm{OD}\left[\delta_{\mathrm{C}} 49.0\right.$ (central line of a septuplet)], and ${ }^{13} \mathrm{C}-4$ of $\mathrm{C}_{5} \mathrm{D}_{5} \mathrm{~N}$ [ $\delta_{\mathrm{C}} 134.3$ (central line of a triplet)], respectively. All the NMR experiments were performed on a Bruker AV300 spectrometer, at $300\left({ }^{1} \mathrm{H}\right)$ and $75.47 \mathrm{MHz}$ $\left({ }^{13} \mathrm{C}\right)$, respectively. Deuterated solvents (purity 99.8\%) were purchased from Sigma-Aldrich (St. Louis, MO, USA). ESI-MS experiments were carried out on a Thermo-TSQ mass spectrometer, by flow injection analysis (FIA), with the electron-spray ionization source (ESI) at $5 \mathrm{kV}$ on TIP capillary. Spectroscopy grade solvents (Sigma-Aldrich) were used. 
Preparative medium-pressure liquid chromatographic (MPLC) separations were carried out on a Biotage Isolera instrument (Biotage, Uppsala, Sweden).

\subsection{Plant Material}

Aerial parts and rhizomes of I. postii Mouterde were separately collected on Korek Mountain (GPS position: $36^{\circ} 35^{\prime} 20^{\prime \prime} \mathrm{N}, 44^{\circ} 27^{\prime} 32^{\prime \prime} \mathrm{E}$ ). The plant was identified by botanist A. $\mathrm{H}$. Al-khayyat of Salahaddin University-Erbil/Iraq. A voucher specimen (accession number 7230) has been deposited at the Education Salahaddin University Herbarium (ESUH). The vegetal materials were cleaned and air-dried under shade at room temperature $\left(20-25^{\circ} \mathrm{C}\right)$ in a ventilated room until they reached constant weight. After drying, each plant part was finely powdered using a laboratory grinding mill, and powdered materials were stored in bottles at room temperature until analyses.

\subsection{Extraction of I. postii and Chromatographic Fractionation of Extracts}

Powdered aerial parts and rhizomes (200 g each) were separately soaked in hexane $(800 \mathrm{~mL})$ with occasional shaking in an ultrasonic bath for $20 \mathrm{~min}$, then left in the same solvent for $5 \mathrm{~h}$ under continuous stirring at room temperature. Subsequently, the mixture was decanted and filtered. This procedure was repeated three times for each part. Defatted rhizomes and aerial parts were subsequently separately suspended in $\mathrm{MeOH}(800 \mathrm{~mL}) \mathrm{n}$ an ultrasonic bath for $20 \mathrm{~min}$ and then left in the same solvent for $5 \mathrm{~h}$ under continuous stirring, at room temperature. The procedure was repeated three times for each vegetable part. The mixtures were then filtered, and the solvent removed under vacuum in a rotary evaporator to afford two crude residues: IPA $(2.6 \mathrm{~g})$ from aerial parts and IPR $(5.5 \mathrm{~g})$ from rhizomes.

Subsequently, IPA (2.5 g) was suspended in $\mathrm{MeOH}-\mathrm{H}_{2} \mathrm{O}(75: 25,350 \mathrm{~mL})$ and extracted with $\mathrm{CH}_{2} \mathrm{Cl}_{2}(3 \times 350 \mathrm{~mL})$ to afford, upon evaporation, a dichloromethane soluble powder $(1.9 \mathrm{~g})$ (IPAD). Then, $500 \mathrm{mg}$ of this residue was separated on a hand-packed reversed phase column (LiChroprep RP18, 25-40 ㅆ 120 g, MerckMillipore, Darmstadt, Germany) using a medium pressure liquid chromatographic (MPLC) instrument (Isolera ONE, Biotage, Uppsala, Sweden). Solvents A and $\mathrm{B}$ of the mobile phase were $\mathrm{H}_{2} \mathrm{O}$ and $\mathrm{MeOH}$, respectively. A linear gradient was applied from a 70:30 A/B mixture to $100 \%$ solvent $\mathrm{B}(\mathrm{MeOH})$, over $30 \mathrm{~min}$ at room temperature, at a flow rate of $30 \mathrm{~mL} / \mathrm{min}$; the detection UV wavelength was set at UV 254-366 nm. Finally, the column was washed with $100 \% \mathrm{MeOH}$ for $3 \mathrm{~min}$ to elute strongly adsorbed compounds. Forty-five fractions ( $20 \mathrm{~mL}$ each) were collected; the solvent in the tubes was evaporated using a centrifuge under vacuum and a liquid nitrogen trap, and the residues were weighed. The overall recovery of the chromatographed mixture was $95 \%$. Then, the content of each fraction was analyzed by TLC on analytical silica gel 60 $\left(\mathrm{GF}_{254}\right.$, Merck, Darmstadt, Germany) plates, eluted with EtOAc $/ n-\mathrm{BuOH} / \mathrm{HCO}_{2} \mathrm{H} / \mathrm{H}_{2} \mathrm{O}$ (5:3:1:1), and on RP-18 (Sigma-Aldrich) plates, eluted with $\mathrm{MeOH} / \mathrm{H}_{2} \mathrm{O}$ (1:1). Spots were detected under UV light at 254 and $366 \mathrm{~nm}$ and by spraying the plates with $0.5 \%$ vanillin in sulfuric acid/EtOH (4:1), followed by heating at $105^{\circ} \mathrm{C}$ for about $1 \mathrm{~min}$. Repeated MPLC separation of main fractions on reversed-phase columns afforded L-tryptophan (29 mg), androsin (66, $13 \mathrm{mg}$ ), apigenin 6-C-glucoside (isovitexin) (109, $45 \mathrm{mg})$, swertisin (111, $17 \mathrm{mg}), 2$ "-O-rhamnosyl swertisin $(\mathbf{1 1 2}, 12 \mathrm{mg})$. A portion of IPR $(5 \mathrm{~g})$ was suspended in $500 \mathrm{~mL}$ of water and partitioned with $500 \mathrm{~mL}$ of $n$-butanol to yield, after evaporation, $2.2 \mathrm{~g}$ of residue IPRB. Then, $1 \mathrm{~g}$ of this mixture was loaded onto a preparative RP-MPLC column installed in the MPLC instrument that was eluted with a gradient of $20-100 \% \mathrm{MeOH}$ in $\mathrm{H}_{2} \mathrm{O}$ for $2 \mathrm{~h}$ at a flow rate of $10 \mathrm{~mL} / \mathrm{min}$. Repeated MPLC chromatographic separations of the main collected fractions on reversed-phase columns afforded trans- $\varepsilon$-viniferin (113, $9 \mathrm{mg})$, trans-resveratrol 3,4'-O-diglucoside (114, $7 \mathrm{mg})$, and isotectorigenin $(\mathbf{1 1 5}, 21 \mathrm{mg})$.

\subsection{Spectroscopic Data of Isolated Compounds}

Androsin (4-O- $\beta$-D-glucopyranosyl-acetovanillone) (66): Colorless powder; TLC (silica gel, $\mathrm{DCM} / \mathrm{MeOH}, 8: 2): \mathrm{R}_{\mathrm{f}}=0.67 ; \mathrm{UV} \lambda_{\max }(\mathrm{MeOH}): 275,308 \mathrm{~nm}$; the molecular formula 
$\mathrm{C}_{15} \mathrm{H}_{20} \mathrm{O}_{8}$ was inferred from the $[\mathrm{M}+\mathrm{Na}]^{+}$ion peak at $m / z 351.23$ in the ESI-MS (positive ion mode) spectrum; ${ }^{1} \mathrm{H}-\mathrm{NMR}\left(300 \mathrm{MHz}, \mathrm{CD}_{3} \mathrm{OD}\right) \delta 7.67(1 \mathrm{H}, \mathrm{dd}, J=8.5$ and $1.9 \mathrm{~Hz}, \mathrm{H}-6)$, $7.60(1 \mathrm{H}, \mathrm{d}, J=1.9 \mathrm{~Hz}, \mathrm{H}-2), 7.25(1 \mathrm{H}, \mathrm{d},=8.5 \mathrm{~Hz}, \mathrm{H}-5), 5.06\left(1 \mathrm{H}, \mathrm{d}, J=7.2 \mathrm{~Hz}, \mathrm{H}-\mathrm{1}^{\prime}\right)$, $3.92\left(3 \mathrm{H}, \mathrm{s}, \mathrm{OCH}_{3}\right), 3.89\left(1 \mathrm{H}, \mathrm{dd}, J=12.0\right.$ and $\left.1.7 \mathrm{~Hz} \mathrm{H}-6^{\prime}{ }_{\mathrm{b}}\right), 3.71(1 \mathrm{H}, \mathrm{dd}, J=12.0$ and $\left.5.2 \mathrm{~Hz} \mathrm{H}-6^{\prime}{ }_{\mathrm{a}}\right), 3.35-3.55\left(4 \mathrm{H}, \mathrm{m}, \mathrm{H}-2^{\prime}, 3^{\prime}, 4^{\prime}, 5^{\prime}\right), 2.59\left(3 \mathrm{H}, \mathrm{s}, \mathrm{COCH}_{3}\right) ;{ }^{13} \mathrm{C}-\mathrm{NMR}(75 \mathrm{MHz}$, $\left.\mathrm{CD}_{3} \mathrm{OD}\right)$ : aglycone moiety: $\delta_{\mathrm{C}} 133.2(0, \mathrm{C}-1), 112.7(1, \mathrm{C}-2), 150.9$ (0, C-3), 152.8 (0, C-4), 116.5 (1, C-5), 124.7 (1, C-6), $199.7(0, \mathrm{C}-7), 26.7(3, \mathrm{C}-8), 56.9\left(3, \mathrm{OCH}_{3}\right)$; glucose moiety: $\delta_{\mathrm{C}}$ $102.1\left(1, \mathrm{C}-1^{\prime}\right), 75.0\left(1, \mathrm{C}-2^{\prime}\right), 78.7\left(1, \mathrm{C}-3^{\prime}\right), 71.5\left(1, \mathrm{C}-4^{\prime}\right), 78.2\left(1, \mathrm{C}-5^{\prime}\right), 62.8\left(2, \mathrm{C}-6^{\prime}\right)$. The numbers in parentheses are the protons attached to the corresponding carbon and were determined by DEPT experiments. The ${ }^{1} \mathrm{H}$ and ${ }^{13} \mathrm{C}$-NMR spectra were in accordance with the literature [81]. Acid hydrolysis $\left(3 \%\right.$ aqueous $\left.\mathrm{H}_{2} \mathrm{SO}_{4}, 80^{\circ} \mathrm{C}, 2 \mathrm{~h}\right)$ provided D-glucose, identical by TLC and comparison of the optical rotation with an authentic sample.

Isovitexin (apigenin 6 - $C$ - $\beta$-glucopyranoside or $4^{\prime}, 5,7$-trihydroxy-6-C- $\beta$-glucopyranoside) (109): Pale yellow powder; TLC (RP-18, $\left.\mathrm{MeOH} / \mathrm{H}_{2} \mathrm{O}, 6: 4\right): \mathrm{Rf}=0.51 ; \mathrm{UV} \lambda_{\max }(\mathrm{MeOH})$ : $270,333 \mathrm{~nm}$; the molecular formula $\mathrm{C}_{21} \mathrm{H}_{20} \mathrm{O}_{10}$ was determined from the $[\mathrm{M}+\mathrm{Na}]^{+}$ion peak at $m / z 455.22$ in the ESI-MS (positive ion mode) spectrum and the [M $-\mathrm{H}]^{-}$ion peak at $m / z 431.20$ in the ESI-MS (negative ion mode) spectrum; ${ }^{1} \mathrm{H}-\mathrm{NMR}\left(300 \mathrm{MHz}, \mathrm{CD}_{3} \mathrm{OD}\right.$ ) aglycone moiety: $\delta 7.83\left(2 \mathrm{H}, \mathrm{d}, J=8.7 \mathrm{~Hz}, \mathrm{H}-2^{\prime}\right.$ and $\left.\mathrm{H}-6^{\prime}\right), 6.93\left(2 \mathrm{H}, \mathrm{d}, J=8.7 \mathrm{~Hz}, \mathrm{H}-3^{\prime}\right.$ and $\left.\mathrm{H}^{\prime} 5^{\prime}\right), 6.59(1 \mathrm{H}, \mathrm{s}, \mathrm{H}-3), 6.50(1 \mathrm{H}, \mathrm{s}, \mathrm{H}-8)$; glucose moiety: $\delta 4.91(1 \mathrm{H}, \mathrm{d}, J=10.0 \mathrm{~Hz}$, H-1"), $4.19\left(1 \mathrm{H}\right.$, distorted $\left.\mathrm{t}, \mathrm{H}-2^{\prime \prime}\right), 3.90\left(1 \mathrm{H}, \mathrm{dd}, J=12.2\right.$ and $\left.1.7 \mathrm{~Hz}, \mathrm{H}-6^{\prime \prime}{ }_{\mathrm{b}}\right), 3.75(1 \mathrm{H}, \mathrm{dd}$, $J=12.0$ and $\left.5.0 \mathrm{~Hz}, \mathrm{H}-6{ }_{\mathrm{a}}\right), 3.52-3.35\left(3 \mathrm{H}, \mathrm{m}, \mathrm{H}-3^{\prime \prime}, 4^{\prime \prime}, 5^{\prime \prime}\right) ;{ }^{13} \mathrm{C}-\mathrm{NMR}\left(75 \mathrm{MHz}, \mathrm{CD}_{3} \mathrm{OD}\right)$ aglycone moiety: $\delta_{\mathrm{C}} 184.0(0, \mathrm{C}-4), 166.1(0, \mathrm{C}-2), 164.9(0, \mathrm{C}-7), 162.8\left(0, \mathrm{C}-4^{\prime}\right), 162.0(0$, C-5), $158.7(0, C-9), 129.4$ (1 and 1, overlapped C-2' and C-6 $\left.{ }^{\prime}\right), 123.1\left(0, C-1^{\prime}\right), 117.0$ (1 and 1, overlapped C-3' and C-5'), $109.2(0, C-6), 105.2(0, C-10), 103.8$ (1, C-3), 95.2 (1, C-8); glucose moiety: $\delta_{C} 82.6\left(1, C-5^{\prime \prime}\right), 80.1\left(1, C-3^{\prime \prime}\right), 75.2\left(1, C-1^{\prime \prime}\right), 72.6\left(1, C-2^{\prime \prime}\right), 71.8\left(1, C-4^{\prime \prime}\right)$, $62.9\left(2, \mathrm{C}-6^{\prime \prime}\right)$. The numbers in parentheses are the protons attached to the corresponding carbon and were determined by DEPT experiments. The ${ }^{1} \mathrm{H}$ - and ${ }^{13} \mathrm{C}-\mathrm{NMR}$ spectra were in accordance with the literature [82]. No rotational isomerism was observed, in accordance with references $[68,83]$.

Swertisin (4',5-dihydroxy-7-methoxyflavone-6-C- $\beta$-D-glucopyranoside) (111): Pale yellow powder; TLC (RP-18, $\left.\mathrm{MeOH} / \mathrm{H}_{2} \mathrm{O}, 6: 4\right): \mathrm{R}_{\mathrm{f}}=0.53 ; \mathrm{UV} \lambda_{\max }(\mathrm{MeOH}): 271,332 \mathrm{~nm}$; IR (nujol): $3360,1650,1605 \mathrm{~cm}^{-1}$; the molecular formula $\mathrm{C}_{22} \mathrm{H}_{22} \mathrm{O}_{10}$ was inferred from the $[\mathrm{M}+\mathrm{Na}]^{+}$ion peak at $m / z 469.29$ in the ESI-MS (positive ion mode) spectrum and the $[\mathrm{M}-\mathrm{H}]^{-}$ion peak at $m / z 445.30$ in the ESI-MS (negative ion mode) spectrum; ${ }^{1} \mathrm{H}-\mathrm{NMR}$ $\left(300 \mathrm{MHz}, \mathrm{CD}_{3} \mathrm{OD}\right) \delta 7.90\left(2 \mathrm{H}, \mathrm{d}, J=8.6 \mathrm{~Hz}, \mathrm{H}-2^{\prime}, 6^{\prime}\right), 6.94\left(2 \mathrm{H}, \mathrm{d}, J=8.6 \mathrm{~Hz}, \mathrm{H}-3^{\prime}, 5^{\prime}\right), 6.76$ $(1 \mathrm{H}, \mathrm{s}, \mathrm{H}-8), 6.67(1 \mathrm{H}, \mathrm{s}, \mathrm{H}-3), 4.87\left(1 \mathrm{H}, \mathrm{d}, J=10.0 \mathrm{~Hz}, \mathrm{H}-1^{\prime \prime}\right), 4.35-4.48$ and $4,15-4.27(1 \mathrm{H}$ overall, $2 \mathrm{~m}, \mathrm{H}-2$ " of two rotamers), $3.96\left(3 \mathrm{H}, \mathrm{s}, \mathrm{OCH}_{3}\right), 3.80-3.95\left(1 \mathrm{H}, \mathrm{m}, \mathrm{H}-6{ }^{\prime \prime}\right), 3.55-3.75$ $\left(1 \mathrm{H}, \mathrm{m}, \mathrm{H}-6{ }_{\mathrm{a}}\right), 3.25-3.45\left(3 \mathrm{H}, \mathrm{m}, \mathrm{H}-3{ }^{\prime \prime}, 4^{\prime \prime}, 5^{\prime \prime}\right) ;{ }^{13} \mathrm{C}-\mathrm{NMR}\left(75 \mathrm{MHz}, \mathrm{C}_{5} \mathrm{D}_{5} \mathrm{~N}\right) \delta_{\mathrm{C}} 181.8(0$, C-4), $163.4\left(0\right.$, C-2) $, 162.2(0, \text { C-7 })^{+}, 162.2(0, \mathrm{C}-5)^{+}, 160.8\left(0, \mathrm{C}-4^{\prime}\right)^{+}, 156.6(0, \mathrm{C}-9), 127.8$ ( 1 and 1 , overlapped $C-2^{\prime}$ and $\left.C-6^{\prime}\right), 120.5\left(0, C-1^{\prime}\right), 115.9$ ( 1 and 1 , overlapped $C-3^{\prime}$ and C-5'), 109.8 (0, C-6), 104.6 (0, C-10), 102.8 (1, C-3), 89.1 (1, C-8), 82.1 (1, C-5"), 79.9 (1, C-3") $73.7\left(1, \mathrm{C}-2^{\prime \prime}\right), 71.4\left(1, \mathrm{C}-1^{\prime \prime}\right)$ \# $, 70.5\left(1, \mathrm{C}-4^{\prime \prime}\right){ }^{\#}, 62.4\left(2, \mathrm{C}-6^{\prime \prime}\right), 55.1\left(3, \mathrm{OCH}_{3}\right) .{ }^{13} \mathrm{C}-\mathrm{NMR}$ $\left(75 \mathrm{MHz}, \mathrm{CD}_{3} \mathrm{OD}\right) \delta_{\mathrm{C}} 183.9(0, \mathrm{C}-4), 166.6(0, \mathrm{C}-2), 166.6(0, \mathrm{C}-7), 164.0\left(0, \mathrm{C}-4^{\prime}\right)^{+}, 163.9$ $(0, C-5)^{+}, 159.1(0, C-9), 129.6\left(1\right.$ and 1 , overlapped C-2 ${ }^{\prime}$ and C- $\left.6^{\prime}\right), 122.4\left(0, C-1^{\prime}\right), 117.4$ (1 and 1, overlapped C- $3^{\prime}$ and C-5'), 110.5 (0, C-6), 106.4 (0, C-10), 103.9 (1, C-3), 91.3 (1, C-8), $82.6\left(1, C-5^{\prime \prime}\right), 80.5\left(1, C-3{ }^{\prime \prime}\right), 74.5$ and $74.8\left(1, C-2{ }^{\prime \prime}\right)^{*}, 72.2$ and $72.4\left(1, C-1{ }^{\prime \prime}\right) *, 71.6$ $\left(1, \mathrm{C}-4^{\prime \prime}\right), 63.4\left(3, \mathrm{C}-6^{\prime \prime}\right), 56.7$ and $57.0\left(3, \mathrm{OCH}_{3}\right){ }^{*} .{ }^{\#},+$ Assignments are interchangeable; * signal duplication indicating the presence of two rotamers, in the ratio of about 52:48, due to restricted rotation around the $C\left(\mathrm{sp}^{3}\right)-C\left(\mathrm{sp}^{2}\right)$ glucosyl-flavone linkage (C-6-C-1") $[68,83]$. The numbers in parentheses are the protons attached to the corresponding carbon and were determined by DEPT experiments.

2"-O- $\alpha$-L-Rhamnosyl swertisin $\left[4^{\prime}, 5\right.$-dihydroxy-7-methoxyflavone-6-C- $(\alpha-\mathrm{L}-\mathrm{rhamnopy-}$ ranosyl- $1 \rightarrow 2-\beta$-D-glucopyranoside)] (112): Yellow powder; TLC (RP-18, $\left.\mathrm{MeOH} / \mathrm{H}_{2} \mathrm{O}, 7: 3\right)$ : $\mathrm{R}_{\mathrm{f}}=0.53$. UV $\lambda_{\max }(\mathrm{MeOH}): 270,332 \mathrm{~nm}$; the molecular formula $\mathrm{C}_{28} \mathrm{H}_{32} \mathrm{O}_{14}$ was inferred 
from the $[\mathrm{M}+\mathrm{Na}]^{+}$ion peak at $m / z 615.50$ in the ESI-MS (positive ion mode) spectrum and the $[\mathrm{M}-\mathrm{H}]^{-}$ion peak at $m / z 591.42$ in the ESI-MS (negative ion mode) spectrum; ${ }^{1} \mathrm{H}-\mathrm{NMR}\left(300 \mathrm{MHz}, \mathrm{CD}_{3} \mathrm{OD}\right) \delta 7.86\left(2 \mathrm{H}, \mathrm{d}, J=8.8 \mathrm{~Hz}, \mathrm{H}-2^{\prime}, 6^{\prime}\right), 6.90(2 \mathrm{H}, \mathrm{d}, J=8.5 \mathrm{~Hz}$, H-3' , 5'), $6.72(1 \mathrm{H}, \mathrm{s}, \mathrm{H}-8), 6.63(1 \mathrm{H}, \mathrm{s}, \mathrm{H}-3), 5.21$ and $5.08(1 \mathrm{H}$ overall, $\mathrm{d}$ and d, $J=1.6 \mathrm{~Hz}$, $\left.\mathrm{H}-1^{\prime \prime \prime}\right)^{*}, 4.91$ and 4.86 (1H overall, $\mathrm{d}$ and $\left.\mathrm{d}, J=9.8 \mathrm{~Hz}, \mathrm{H}-1^{\prime \prime}\right) *, 4.52$ and 4.46 (1H overall, dd and $\mathrm{dd}, J=9.6$ and $\left.8.6 \mathrm{~Hz}, \mathrm{H}-2^{\prime \prime}\right) *, 3.92$ and $3.89\left(3 \mathrm{H}\right.$ overall, $\mathrm{s}$ and $\left.\mathrm{s}, 7-\mathrm{OCH}_{3}\right) *, 3.85-3.95$ $\left(\mathrm{m}, 2 \mathrm{H}, \mathrm{H}-6^{\prime \prime}{ }_{\mathrm{b}}\right.$ and H-2 $\left.{ }^{\prime \prime \prime}\right), 3.60-3.75\left(1 \mathrm{H}, \mathrm{m}, \mathrm{H}-6^{\prime \prime}{ }_{\mathrm{a}}\right), 3.50\left(1 \mathrm{H}, \mathrm{t}, J=8.8 \mathrm{~Hz}, \mathrm{H}-3{ }^{\prime \prime}\right), 3,39(1 \mathrm{H}$, $\left.\mathrm{t}, J=9.0 \mathrm{~Hz}, \mathrm{H}-3^{\prime \prime \prime}\right) *$ * 3.30-3.45 (3H, m, H-4", H-5", $\left.\mathrm{H}-3^{\prime \prime \prime}\right), 3.08\left(1 \mathrm{H}, \mathrm{t}, J=9.5 \mathrm{~Hz}, \mathrm{H}-4^{\prime \prime \prime}\right)$, 2.30-2.40 and 2.60-2.70 (1H overall, $\mathrm{m}$ and $\left.\mathrm{m}, \mathrm{H}-5^{\prime \prime \prime}\right)^{*}, 0.69$ and $0.62(3 \mathrm{H}$ overall, $\mathrm{d}$ and $\left.\mathrm{d}, J=6.2 \mathrm{~Hz}, \mathrm{H}_{3}-6^{\prime \prime \prime}\right) *{ }^{13} \mathrm{C}-\mathrm{NMR}\left(75 \mathrm{MHz}, \mathrm{CD}_{3} \mathrm{OD}\right) \delta_{\mathrm{C}} 184.0$ and $184.3(0, \mathrm{C}-4) *, 166.5$ and $166.7(0, \mathrm{C}-7)$ *, $165.4(0, \mathrm{C}-2), 162.9$ and $163.0\left(0, \mathrm{C}-4^{\prime}\right)$ *, 161.2 and $161.7(0, \mathrm{C}-5)^{*}$, 159.1 and $159.3(0, C-9) *, 129.5$ and $129.6\left(1\right.$ and 1 , overlapped $C-2^{\prime}$ and $\left.C-6^{\prime}\right) *, 123.0$ and $122.9\left(0, \mathrm{C}-1^{\prime}\right)^{*}, 117.1\left(1\right.$ and 1 , overlapped $C-3^{\prime}$ and $\left.C-5^{\prime}\right), 110.7$ and $111.0(0, C-6), 105.9$ and $106.4(0, \mathrm{C}-10), 104.1$ and $104.3(1, \mathrm{C}-3)^{*}, 102.2$ and $103.0\left(1, \mathrm{C}-1^{\prime \prime \prime}\right) *, 91.6$ and 92.2 $(1, \mathrm{C}-8)^{*}, 82.4$ and $82.5\left(1, \mathrm{C}-5^{\prime \prime}\right) *, 81.3$ and $81.7\left(1, \mathrm{C}-3^{\prime \prime}\right), 76.8$ and $78.9\left(1, \mathrm{C}-2^{\prime \prime}\right) *, 73.5$ and $73.7\left(1, \mathrm{C}-4^{\prime \prime \prime}\right) *, 72.8$ and $73.2\left(1, \mathrm{C}-1^{\prime \prime}\right)^{*}, 72.4\left(1, \mathrm{C}-2^{\prime \prime \prime}\right)^{+}, 72.0,72.1$ and $72.2(1$ and $1, \mathrm{C}-4^{\prime \prime}$ and $\left.\mathrm{C}-3^{\prime \prime \prime}\right)^{*,+}, 69.9\left(1, \mathrm{C}-5^{\prime \prime \prime}\right), 63.3\left(2, \mathrm{C}-6^{\prime \prime}\right), 56.7$ and $57.1\left(3,7-\mathrm{OCH}_{3}\right) *, 18.0$ and $18.2\left(3, \mathrm{C}-6^{\prime \prime \prime}\right){ }^{*}$ Signal duplication due to the presence of two rotamers $[68,83]$ in the ratio of about 62:38; ${ }^{+}$assignments are interchangeable. The numbers in parentheses are the protons attached to the corresponding carbon and were determined by DEPT experiments. Proton and carbon signals were assigned on the basis of COSY, HSQC, HMBC (112A), and NOESY correlations. Acid hydrolysis ( $\%$ aqueous $\left.\mathrm{H}_{2} \mathrm{SO}_{4}\right)$ of 112 yielded swertisin (111) as the aglycone, and L-rhamnose, compared with an authentic sample by TLC and optical rotation.

Trans- $\varepsilon$-viniferin (113): Pale yellow powder; mp: $148-150{ }^{\circ} \mathrm{C} ; \mathrm{UV} \lambda_{\max }(\mathrm{MeOH}): 220$, 305 and $320 \mathrm{~nm}$; IR (nujol) 3350, 1610, 1575, 1505, 1330, 1256, $1160 \mathrm{~cm}^{-1}$; the molecular formula $\mathrm{C}_{28} \mathrm{H}_{22} \mathrm{O}_{6}$ was inferred from the $[\mathrm{M}+\mathrm{H}]^{+},[\mathrm{M}+\mathrm{Na}]^{+}$and $[2 \mathrm{M}+\mathrm{Na}]^{+}$ion peaks at $m / z$ 455.20, 477.21 and 930.94, respectively, in the ESI-MS (positive ion mode) spectrum and the $[\mathrm{M}-\mathrm{H}]^{-}$ion peak at $m / z 453.31$ in the ESI-MS (negative ion mode) spectrum; ${ }^{1} \mathrm{H}-\mathrm{NMR}\left(300 \mathrm{MHz}, \mathrm{CD}_{3} \mathrm{OD}\right) \delta 7.11\left(2 \mathrm{H}, \mathrm{d}, J=8.5 \mathrm{~Hz}, \mathrm{H}-2^{\prime}\right.$ and $\left.\mathrm{H}-6^{\prime}\right), 7.01(2 \mathrm{H}, \mathrm{d}, J=8.5$ $\mathrm{Hz}, \mathrm{H}-2$ and H-6), $6.79\left(1 \mathrm{H}, \mathrm{d}, J=16.4 \mathrm{~Hz}, \mathrm{H}-7^{\prime}\right), 6.74\left(2 \mathrm{H}, \mathrm{d}, J=8.5 \mathrm{~Hz}, \mathrm{H}-3^{\prime}\right.$ and $\left.\mathrm{H}-5^{\prime}\right)$, $6.62\left(2 \mathrm{H}, \mathrm{d}, J=8.5 \mathrm{~Hz}, \mathrm{H}-3\right.$ and H-5), $6.60\left(1 \mathrm{H}, \mathrm{d}, J=1.8 \mathrm{~Hz}, \mathrm{H}-14^{\prime}\right), 6.54(1 \mathrm{H}, \mathrm{d}, J=16.3$ $\left.\mathrm{Hz}, \mathrm{H}-8^{\prime}\right), 6.22\left(1 \mathrm{H}, \mathrm{d}, J=1.8 \mathrm{~Hz}, \mathrm{H}-12^{\prime}\right), 6.16-6.14(3 \mathrm{H}, \mathrm{m}, \mathrm{H}-10, \mathrm{H}-12$ and $\mathrm{H}-14), 5.33(1 \mathrm{H}$, $\mathrm{d}, J=6.6 \mathrm{~Hz}, \mathrm{H}-7), 4.32(1 \mathrm{H}, \mathrm{d}, J=6.6 \mathrm{~Hz}, \mathrm{H}-8) ;{ }^{13} \mathrm{C}-\mathrm{NMR}\left(75 \mathrm{MHz}, \mathrm{CD}_{3} \mathrm{OD}\right) \delta_{\mathrm{C}} 162.7(0$, C-11 $\left.{ }^{\prime}\right), 160.1\left(0\right.$ and 0 , overlapped C-11 and C-13), $159.8\left(0, \mathrm{C}-13^{\prime}\right)^{+}, 158.5\left(0, \mathrm{C}^{+} 4^{\prime}\right)^{+}, 158.4$ $(0, \mathrm{C}-4)^{+}, 147.4(0, \mathrm{C}-9), 136.9\left(0, \mathrm{C}^{\prime} 9^{\prime}\right), 133.9(0, \mathrm{C}-1), 130.4\left(0, \mathrm{C}-1^{\prime}\right), 130.3\left(1, \mathrm{C}-7^{\prime}\right), 128.8(1$ and 1, overlapped C-2 ${ }^{\prime}$ and $\left.C-6^{\prime}\right), 128.2$ ( 1 and 1 , overlapped C-2 and C-6), $123.7\left(1, C-8^{\prime}\right)$, $120.1\left(0, C-10^{\prime}\right), 116.4$ (1 and 1, overlapped C-3 and C-5), 116.3 (1 and 1, overlapped C-3' and $\left.C-5^{\prime}\right), 107.4$ (1 and 1, overlapped C-10 and C-14), $104.4\left(1, \mathrm{C}-14^{\prime}\right), 102.3$ (1, C-12), 96.9 $\left(1, \mathrm{C}-12^{\prime}\right), 94.8(1, \mathrm{C}-7)$, and $58.3(1, \mathrm{C}-8){ }^{+}{ }^{+}$assignments are interchangeable. The numbers in parentheses are the protons attached to the corresponding carbon and were determined by DEPT experiments. The NMR spectra matched those reported in literature [84,85]; however, some assignments were corrected.

Resveratrol 3,4'-O-di- $\beta$-D-glucopyranoside (114): Pale yellow powder; the molecular formula $\mathrm{C}_{26} \mathrm{H}_{32} \mathrm{O}_{13}$ was inferred from the $[\mathrm{M}+\mathrm{Na}]^{+}$ion peak at $m / z 575.28$ in the ESI-MS (positive-ion mode) spectrum; ${ }^{1} \mathrm{H}-\mathrm{NMR}\left(300 \mathrm{MHz}, \mathrm{CD}_{3} \mathrm{OD}\right) \delta 7.44\left(2 \mathrm{H}, \mathrm{d}, J=8.7 \mathrm{~Hz}, \mathrm{H}-2^{\prime}\right.$ and $\left.\mathrm{H}-6^{\prime}\right), 7.05\left(2 \mathrm{H}, \mathrm{d}, J=8.7 \mathrm{~Hz}, \mathrm{H}-3^{\prime}\right.$ and $\left.\mathrm{H}-5^{\prime}\right), 7.03(1 \mathrm{H}, \mathrm{d}, J=16.4 \mathrm{~Hz}, \mathrm{H}-8), 6.90(1 \mathrm{H}$, $\mathrm{d}, J=16.4 \mathrm{~Hz}, \mathrm{H}-7), 6.78(1 \mathrm{H}$, br s, H-2), $6.57(1 \mathrm{H}$, br s, H-6), $6.44(1 \mathrm{H}, \mathrm{t}, J=2.1 \mathrm{~Hz}, \mathrm{H}-4)$, $4.89\left(1 \mathrm{H}, \mathrm{d}, J=8.0 \mathrm{~Hz}, \mathrm{H}-1^{\prime \prime}\right)^{+}, 4.86\left(1 \mathrm{H}, \mathrm{d}, J=8.0 \mathrm{~Hz}, \mathrm{H}-1^{\prime \prime \prime}\right)^{+}, 3.85-3.97\left(2 \mathrm{H}, \mathrm{m}, \mathrm{H}-6^{\prime \prime}{ }_{\mathrm{b}}\right.$ and $\left.\mathrm{H}-6^{\prime \prime \prime}{ }_{\mathrm{b}}\right), 3.67\left(2 \mathrm{H}\right.$, two overlapped dd, $J=12.0$ and $5.1 \mathrm{~Hz}, \mathrm{H}-6^{\prime \prime}{ }_{\mathrm{a}}$ and $\left.\mathrm{H}-6^{\prime \prime \prime}{ }_{\mathrm{a}}\right), 3.35-3.50(8 \mathrm{H}$, m, H-2" , H-2 $\left.{ }^{\prime \prime \prime}, \mathrm{H}-3^{\prime \prime}, \mathrm{H}-3^{\prime \prime \prime}{ }^{\prime \prime} \mathrm{H}-4^{\prime \prime}, \mathrm{H}-4^{\prime \prime \prime}, \mathrm{H}-5^{\prime \prime}, \mathrm{H}-5^{\prime \prime \prime}\right) ;{ }^{+}$assignments are interchangeable; ${ }^{13} \mathrm{C}-\mathrm{NMR}\left(75 \mathrm{MHz}, \mathrm{CD}_{3} \mathrm{OD}\right) \delta_{\mathrm{C}} 160.5$ (0, C-3), 159.6 (0, C-5), 158.8 (0, C-4'), 141.1 (0, C-1), 133,1 (0, C-1' $), 129.4(1, \mathrm{C}-8), 128.7$ (1 and 1, overlapped C-2' and C-6'), $128.2(1, \mathrm{C}-7), 117.9(1$ and 1, overlapped C-3' and C-5'), 108.5 (1, C-6), 107.1 (1, C-2), $104.4(1, \mathrm{C}-4), 102.4$ and 102.2 
(1 each, C-1" and C-1"' $), 78.4,78.3,78.2,78,1$ (1 each, C-5", C-5 ${ }^{\prime \prime \prime}, C-3^{\prime \prime}$ and C-3"'), 74.9 and 74.9 ( 1 each, C-2" and C-2'"'), 71.5 and 71.4 ( 1 each, C-4" and C-4"' $), 62.6$ and 62.5 (2 each, C-6" and C- $\left.6^{\prime \prime \prime}\right)$. The numbers in parentheses are the protons attached to the corresponding carbon and were determined by DEPT experiments. Signal assignments to protons and carbons were established on the basis of COSY, HSQC, HMBC, and NOESY correlations. The data are in accordance with those reported in literature [86]. Acid hydrolysis (3\% aqueous $\mathrm{H}_{2} \mathrm{SO}_{4}$ ) provided D-glucose, identical by TLC and comparison of the optical rotation with an authentic sample.

Isotectorigenin (pseudotectorigenin or psi-tectorigenin) $\left(4^{\prime}, 5,7\right.$-trihydroxy-8-methoxyisoflavone) (115): Pale yellow powder, TLC (RP-18, $\left.\mathrm{MeOH} / \mathrm{H}_{2} \mathrm{O}, 8: 2\right): \mathrm{R}_{\mathrm{f}}=0.52$. UV $\lambda_{\max }$ (MeOH): 269, 336 (sh) nm; the molecular formula $\mathrm{C}_{16} \mathrm{H}_{12} \mathrm{O}_{6}$ was inferred from the [2M $+\mathrm{Na}^{+}$ion peak at $m / z 622.97$ and the $[\mathrm{M}+\mathrm{Na}]^{+}$ion peak at $m / z 323.12$ in the ESI-MS (positive ion mode) spectrum, and the $[\mathrm{M}-\mathrm{H}]^{-}$ion peak at $m / z 299.17$ in the ESI-MS (negative ion mode) spectrum. ${ }^{1} \mathrm{H}-\mathrm{NMR}\left(300 \mathrm{MHz}, \mathrm{CD}_{3} \mathrm{OD}\right) \delta 7.81(1 \mathrm{H}, \mathrm{s}, \mathrm{H}-2), 7.30(2 \mathrm{H}, \mathrm{d}$, $\left.J=8.4 \mathrm{~Hz}, \mathrm{H}-2^{\prime}, 6^{\prime}\right), 6.79\left(2 \mathrm{H}, \mathrm{d}, J=8.4 \mathrm{~Hz}, \mathrm{H}-3^{\prime}, 5^{\prime}\right), 6.09(1 \mathrm{H}, \mathrm{s}, \mathrm{H}-6), 3.77\left(3 \mathrm{H}, \mathrm{s}, 8-\mathrm{OCH}_{3}\right)$. ${ }^{13} \mathrm{C}-\mathrm{NMR}\left(75 \mathrm{MHz}, \mathrm{CD}_{3} \mathrm{OD}\right) \delta_{\mathrm{C}} 181.0$ (0, C-4), 159.7 (0, C-7), 158.8 (0, C-4'), 156.7 (0, C-9), 153.7 (0, C-5), 153.3 (1, C-2), 137.2 (0, C-8), 131.5 (1 and 1, C-2' and C-6' $), 124.1(0, \mathrm{C}-3), 123.4$ $\left(0, \mathrm{C}-1^{\prime}\right), 116.3\left(1\right.$ and $1, \mathrm{C}-3^{\prime}$ and $\left.\mathrm{C}-5^{\prime}\right), 102.3(0, \mathrm{C}-10), 98.2(1, \mathrm{C}-6), 60.6\left(3,8-\mathrm{OCH}_{3}\right)$. The numbers in parentheses are the protons attached to the corresponding carbon and were determined by DEPT experiments. Proton and carbon signals were assigned on the basis of HSQC, HMBC, and NOESY correlations. The data are in accordance with those reported in literature [87].

\subsection{Free Radical Scavenging Activity}

Briefly, a $0.3 \mathrm{mM}$ solution of DPPH in MeOH was prepared. To $1 \mathrm{~mL}$ of this solution, $3 \mathrm{~mL}$ of sample or extract solution in $10 \%$ aqueous $\mathrm{MeOH}$ at different concentrations (10, $25,50,100,150,200,250,350 \mu \mathrm{g} / \mathrm{mL}$ ) was added. Subsequently, the mixture was shaken vigorously and incubated for $30 \mathrm{~min}$ at $22{ }^{\circ} \mathrm{C}$ in the dark until a stable absorbance value (A) at $517 \mathrm{~nm}$ was obtained, that was measured using a UV-Visible spectrophotometer (Lambda 25 UV/Vis spectrometer N.3903, Perkin Elmer instruments, Waltham, MA, USA). A lower absorbance of the reaction mixture indicated higher free radical scavenging (FRS) activity. The DPPH solution (1 mL), plus 10\% $\mathrm{MeOH}(3 \mathrm{~mL})$, was used as the control. The FRS\% was calculated using the formula: $\left[1-\left(\mathrm{A}_{\text {sample }} / \mathrm{A}_{\text {control }}\right)\right] \times 100$. The curve of the $\%$ scavenging activity against the concentration was plotted for each sample using the MS Excel-based program to calculate the $\mathrm{EC}_{50}$ value, i.e., the concentration $(\mu \mathrm{g} / \mathrm{mL}$ or $\mu \mathrm{M} / \mathrm{L}$ ) of the sample required to scavenge $50 \%$ of the initial DPPH concentration. Each analysis was carried out in triplicate and the mean $\pm \mathrm{SD}(n=3)$ was calculated. Ascorbic acid (Sigma-Aldrich) was used as a standard antiradical agent. The lower the $\mathrm{EC}_{50}$ value, the higher the sample antiradical activity. The antiradical activity was also expressed as ascorbic acid equivalents (AAEs) (Table 2), i.e., $\mu$ g ascorbic acid equivalents $/ \mu \mathrm{g}$ sample. These values were calculated using the formula: $\mathrm{EC}_{50}$ ascorbic acid $(\mu \mathrm{g} / \mathrm{mL}) / \mathrm{EC}_{50}$ sample $(\mu \mathrm{g} / \mathrm{mL})[77]$.

\subsection{Total Antioxidant Capacity (TAOC_Ammonium Phosphomolybdate Assay)}

Briefly, samples of dry extracts or standard ascorbic acid, dissolved in $\mathrm{MeOH} /$ distilled $\mathrm{H}_{2} \mathrm{O}$ (50:50), were combined with $3.0 \mathrm{~mL}$ of reagent solution ( $0.6 \mathrm{M}$ sulfuric acid, $28 \mathrm{mM}$ sodium phosphate and $4 \mathrm{mM}$ ammonium molybdate) to achieve a series of eight final concentrations in the range of $12-450 \mu \mathrm{g} / \mathrm{mL}$. The tubes were capped and incubated in a boiling water bath at $95{ }^{\circ} \mathrm{C}$ for $90 \mathrm{~min}$. The samples were cooled to $22^{\circ} \mathrm{C}$ and absorbance was measured at $695 \mathrm{~nm}$ against the blank using the cited UV-Visible spectrophotometer. From each series of measures, a sigmoidal curve was obtained by data interpolation and the $\mathrm{EC}_{50}$ value of each sample was calculated as the concentration corresponding to $50 \%$ activity. The blank contained $3.0 \mathrm{~mL}$ of the reagent solution and $0.3 \mathrm{~mL}$ of $\mathrm{MeOH} /$ distilled $\mathrm{H}_{2} \mathrm{O}$ (50:50), and it was incubated under the same conditions as the samples. Each analysis 
was carried out in triplicate and the mean $\pm \mathrm{SD}(n=3)$ was calculated. The TAOC values were expressed as $\mu \mathrm{g}$ ascorbic acid equivalents $/ \mu \mathrm{g}$ extract (Table 2 ). They were calculated using the formula: $\mathrm{EC}_{50}(\mu \mathrm{g} / \mathrm{mL})$ ascorbic acid) $/ \mathrm{EC}_{50}(\mu \mathrm{g} / \mathrm{mL})$ extract. The $\mathrm{EC}_{50}$ of ascorbic acid used in TAOC calculation was $26.12 \pm 0.56 \mu \mathrm{g} / \mathrm{mL}$.

\subsection{Acid Hydrolysis of Compounds $\mathbf{1 1 2}$ and $\mathbf{1 1 4}$}

Compounds 112 and 114 (2.0 mg each) were separately dissolved in 3\% aqueous $\mathrm{H}_{2} \mathrm{SO}_{4}$ in a sealed vial and heated at $90{ }^{\circ} \mathrm{C}$ for $45 \mathrm{~min}$. After cooling to room temperature and extraction with $\mathrm{CHCl}_{3}$, the aqueous layer was repeatedly evaporated to dryness with the aid of MeCN. The residues were identified as L-(+)-rhamnose and D-(+)-glucose, respectively, by TLC and optical rotation upon comparison with authentic samples.

\section{Conclusions}

A dozen Iris species are used in the traditional medicine of Kurdistan. In the first part of this paper, we have reported the structures of the main constituents, traditional uses and biological activities found in the literature for the few species growing in Kurdistan that have been investigated so far. The most characteristic secondary metabolites are various terpenoids, among which iridal derivatives are the most typical ones, and phenolic derivatives, among which isoflavones predominate. Most of these Iris metabolites exhibited various bioactivities. Based on these data, we then investigated, for the first time, the contents of the methanolic extracts of $I$. postii aerial parts and rhizomes. L-tryptophan, androsin (66), apigenin 6-C-glucoside (isovitexin) (109), swertisin (111), and 2"-O-rhamnosyl swertisin (112) were isolated from the aerial parts, whereas chromatographic separation of the extract from rhizomes afforded trans- $\varepsilon$-viniferin (113), trans-resveratrol 3,4'-O-diglucoside (114), and isotectorigenin (115). To the best of our knowledge, this is the first finding of compounds 112-115 in the genus Iris. Isolated compounds showed a wide range of bioactivities, in addition to the excellent radical-scavenging properties exhibited in this investigation by 2 "-O- $\alpha$-L-rhamnosyl- swertisin (112), $\varepsilon$-viniferin (113), and resveratrol 3,4'-O-di- $\beta$-Dglucopyranoside (114). Thus, isovitexin (109) has been reported to be an anti-inflammatory, antihyperglycemic, sedative agent with insulin secretagogue properties and to display antioxidant, anti-inflammatory, neuroprotective, anti-diabetic, antitumor effects [88,89]; swertisin (111) exhibited antioxidant, anti-inflammatory, antihyperglycemic activities with insulin secretagogue and adenosine A1 receptor antagonist properties [90]; swertisin (111) and 2"-O-rhamnosylswertisin (112) exhibited strong $\alpha$-glucosidase inhibitory activity in vitro [91] and effective mechanical antinociceptive properties [81]; $\varepsilon$-viniferin exhibited relatively strong inhibition of $\alpha$-glucosidase in vitro [92] and inhibited both human LDL and HDL oxidation in vitro [85]; resveratrol diglucoside 114 decreased ethanol-induced oxidative DNA damage in mouse brain cells, possibly via inhibition of oxidative stress [93], and displayed highly selective antiproliferative activity against tumor cells [94].

In conclusion, the few Iris species growing in Kurdistan that have been investigated so far demonstrated to be novel viable sources of various bioactive compounds. Moreover, the remarkable antioxidant and radical scavenging activities of the methanol extracts of aerial parts and rhizomes of I. postii, as well as the anti-inflammatory properties reported for different isolated compounds, validate the traditional medicinal use of this plant in Kurdistan. Further studies aimed to evaluate the in vivo potential of Iris extracts in various models and to isolate and identify the antioxidant principles occurring in the most polar fractions of the methanolic extract of $I$. postii aerial parts shall be carried out in due time.

Supplementary Materials: NMR and MS spectra of isolated compounds are available online, Figure S1: ${ }^{1} \mathrm{H}-\mathrm{NMR}$ spectrum $\left(300 \mathrm{MHz}, \mathrm{CD}_{3} \mathrm{OD}\right)$ of androsin, Figure S2: ${ }^{13} \mathrm{C}-\mathrm{NMR}$ spectrum (75 MHz, $\mathrm{CD}_{3} \mathrm{OD}$ ) of androsin, Figure S3: ESI-MS (positive ion mode) spectrum of androsin, Figure S4: ${ }^{1} \mathrm{H}-\mathrm{NMR}$ spectrum $\left(300 \mathrm{MHz}, \mathrm{CD}_{3} \mathrm{OD}\right)$ of isovitexin, Figure S5: ${ }^{13} \mathrm{C}-\mathrm{NMR}$ spectrum (75 MHz, $\mathrm{CD}_{3} \mathrm{OD}$ ) of isovitexin, Figure S6: ESI-MS (positive ion mode) spectrum of isovitexin, Figure S7: ESI-MS (negative ion mode) spectrum of isovitexin, Figure S8: ${ }^{1} \mathrm{H}-\mathrm{NMR}$ spectrum $\left(300 \mathrm{MHz}, \mathrm{CD}_{3} \mathrm{OD}\right)$ of swertisin, Figure S9: ${ }^{13} \mathrm{C}-\mathrm{NMR}$ spectrum $\left(75 \mathrm{MHz}, \mathrm{CD}_{3} \mathrm{OD}\right)$ of swertisin, 
Figure S10: ${ }^{13} \mathrm{C}-\mathrm{NMR}$ spectrum $\left(75 \mathrm{MHz}, \mathrm{C}_{5} \mathrm{D}_{5} \mathrm{~N}\right)$ of swertisin, Figure S11: ESI-MS (positive ion mode) spectrum of swertisin, Figure S12: ESI-MS (negative ion mode) spectrum of swertisin, Figure S13: ${ }^{1} \mathrm{H}-\mathrm{NMR}$ spectrum $\left(300 \mathrm{MHz}, \mathrm{CD}_{3} \mathrm{OD}\right.$ ) of 2"-O- $\alpha$-L-rhamnosyl swertisin, Figure S14: COSY spectrum of $2 "$-O- $\alpha$-L-rhamnosyl swertisin, Figure S15: ${ }^{13} \mathrm{C}-\mathrm{NMR}$ spectrum $\left(75 \mathrm{MHz}, \mathrm{CD}_{3} \mathrm{OD}\right)$ of 2"-O- $\alpha$-L-rhamnosyl swertisin, Figure S16: HSQC spectrum of 2"-O- $\alpha$-L-rhamnosyl swertisin, Figure S17: HMBC spectrum of 2"-O- $\alpha$-L-rhamnosyl swertisin, Figure S18: HMBC spectrum (enlargement 1) of 2"-O- $\alpha$-L-rhamnosyl swertisin, Figure S19: HMBC spectrum (enlargement 2) of 2 "-O- $\alpha$-L-rhamnosyl swertisin, Figure S20: NOESY spectrum of 2 "-O- $\alpha$-L-rhamnosyl swertisin, Figure S21: ESI-MS spectra (positive and negative ion mode) of 2 "-O- $\alpha$-L-rhamnosyl swertisin, Figure S22: ${ }^{1} \mathrm{H}-\mathrm{NMR}$ spectrum $\left(300 \mathrm{MHz}, \mathrm{CD}_{3} \mathrm{OD}\right)$ of tryptophan, Figure S23: ${ }^{13} \mathrm{C}-\mathrm{NMR}$ spectrum (75 MHz, $\mathrm{CD}_{3} \mathrm{OD}$ ) of tryptophan, Figure S24: ESI-MS (positive ion mode) spectrum of tryptophan, Figure S25: ${ }^{1} \mathrm{H}-\mathrm{NMR}$ spectrum $\left(300 \mathrm{MHz}, \mathrm{CD}_{3} \mathrm{OD}\right)$ of isotectorigenin, Figure S26: ${ }^{13} \mathrm{C}-\mathrm{NMR}$ spectrum $\left(75 \mathrm{MHz}, \mathrm{CD}_{3} \mathrm{OD}\right)$ of isotectorigenin, Figure S27: ESI-MS (positive ion mode) spectrum of isotectorigenin, Figure S28: ESI-MS (negative ion mode) spectrum of isotectorigenin, Figure S29: ${ }^{1} \mathrm{H}-\mathrm{NMR}$ spectrum $\left(300 \mathrm{MHz}, \mathrm{CD}_{3} \mathrm{OD}\right)$ of trans- $\varepsilon$-viniferin, Figure S30: ${ }^{13} \mathrm{C}-\mathrm{NMR}$ spectrum $(75 \mathrm{MHz}$, $\mathrm{CD}_{3} \mathrm{OD}$ ) of trans- $\varepsilon$-viniferin, Figure S31: ESI-MS (positive ion mode) spectrum of trans- $\varepsilon$-viniferin, Figure S32: ESI-MS (negative ion mode) spectrum of trans- $\varepsilon$-viniferin, Figure S33: ${ }^{1} \mathrm{H}-\mathrm{NMR}$ spectrum $\left(300 \mathrm{MHz}, \mathrm{CD}_{3} \mathrm{OD}\right)$ of resveratrol-3,4'-O-di- $\beta$-D-glucopyranoside, Figure S34: ${ }^{13} \mathrm{C}-\mathrm{NMR}$ spectrum (75 MHz, CD 3 OD) of resveratrol-3,4'-O-di- $\beta$-D-glucopyranoside, Figure S35: HSQC spectrum of resveratrol 3,4'-O-di- $\beta$-D-glucopyranoside, Figure S36: HMBC spectrum of resveratrol-3,4'-O-di$\beta$-D-glucopyranoside, Figure S37: NOESY spectrum of resveratrol 3,4'-O-di- $\beta$-D-glucopyranoside, Figure S38: ESY-MS spectrum (positive ion mode) of resveratrol-3,4'-O-di- $\beta$-D-glucopyranoside.

Author Contributions: Conceptualization and supervision, G.V. and F.H.S.H.; data curation, Z.M.T. and H.I.M.A.; investigation, H.I.M.A., G.G., S.K.N. and M.F.I.; writing original draft, G.V.; writingreview and editing, G.V., F.H.S.H. and G.G. All authors have read and agreed to the published version of the manuscript.

Funding: This research received no external funding.

Data Availability Statement: Raw data are available in supplementary material.

Acknowledgments: The authors are indebted to Abdul Hussain Al Khayyat and Abdullah S. A., the University of Salahaddin-Erbil, Iraq, for the plant identification. Raffaella Gaggeri, Dipartimento di Scienze del Farmaco, and Daniela Buonocore, Dipartimento di Biologia e Biotecnologie, University of Pavia, are thanked for technical assistance in the DPPH and TAOC assays. The Universidad Técnica Particular de Loja (UTPL) is acknowledged for supporting open access publication.

Conflicts of Interest: The authors declare no conflict of interest.

Sample Availability: Samples of the compounds are not available from the authors.

\section{References}

1. Nedhal, A.; Luay, Y. A survey of plants used in Iraqi traditional medicine. Jordan J. Pharm. Sci. 2010, 3, 100-107.

2. Solecki, R.S. Shanidar IV, a Neanderthal Flower Burial in Northern Iraq. Science 1975, 190, 880-881. [CrossRef]

3. Nahida, A. The most medicinal plants used in Iraq: Traditional knowledge. Adv. Environ. Biol. 2011, 5, 401-406.

4. Mati, E.; De Boer, H. Ethnobotany and trade of medicinal plants in the Qaysari Market, Kurdish Autonomous Region, Iraq. J. Ethnopharmacol. 2011, 133, 490-510. [CrossRef] [PubMed]

5. Amin, H.I.M.; Ibrahim, M.F.; Hussain, F.H.S.; Sardar, A.S.; Vidari, G. Phytochemistry and ethnopharmacology of some me-dicinal plants used in the Kurdistan region of Iraq. Nat. Prod. Commun. 2016, 11, 291-296. [PubMed]

6. WCSP. World Checklist of Selected Plant Families. Available online: Wcsp.science.kew.org (accessed on 2 June 2014).

7. Iris. Pacific Bulb Society. Available online: https://www.pacificbulbsociety.org (accessed on 3 March 2012).

8. Kaššák, P. Secondary metabolites of the chosen genus Iris species. Acta Univ. Agric. Silvic. Mendel. Brun. 2012, 60, 269-280. [CrossRef]

9. Kukula-Koch, W.; Sieniawska, E.; Widelski, J.; Urjin, O.; Głowniak, P.; Skalicka-Woźniak, K. Major secondary metabolites of Iris spp. Phytochem. Rev. 2015, 14, 51-80. [CrossRef]

10. Brenna, E.; Fuganti, C.; Serra, S. From commercial racemic fragrances to odour active enantiopure compounds: The ten isomers of irone. C. R. Chim. 2003, 6, 529-546. [CrossRef]

11. Townsend, C.; Guest, E. (Eds.) Flora of Iraq, Vol. 8: Monocotyledons; Baghdad-Ministry of Agriculture \& Agrarian Reform: Baghdad, Iraq, 1985. 
12. Amin, H.I.M.; Amin, A.A.; Tosi, S.; Mellerio, G.G.; Hussain, F.H.S.; Picco, A.M.; Vidari, G. Chemical composition and anti-fungal activity of essential oils from flowers, leaves, rhizomes, and bulbs of the wild Iraqi Kurdish plant Iris persica. Nat. Prod. Commun. 2017, 12, 441-444.

13. Amin, H.I.M.; Hussain, F.H.S.; Maggiolini, M.; Vidari, G. Bioactive constituents from the traditional Kurdish plant Iris persica. Nat. Prod. Commun. 2018, 13, 1127-1128. [CrossRef]

14. Rahman, A.-U.; Nasim, S.; Baig, I.; Jalil, S.; Orhan, I.; Sener, B.; Choudary, M.I. Antiinflammatory isoflavonoids from rhizomes of Iris germanica. J. Ethnopharmacol. 2003, 86, 177-180. [CrossRef]

15. Schütz, C.; Quitschau, M.; Hamburger, M.; Potterat, O. Profiling of isoflavonoids in Iris germanica rhizome extracts by microprobe NMR and HPLC-PDA-MS analysis. Fitoterapia 2011, 82, 1021-1026. [CrossRef] [PubMed]

16. Shojaii, A.; Haghjoo, E.; Parvizi, M.M. Efficacy of topical herbal remedies for insomnia in Iranian traditional medicine. Pharmacogn. Res. 2019, 11, 188. [CrossRef]

17. Rahman, A.-U.; Nasim, S.; Baig, I.; Orhan, I.E.; Şener, B.; Ayanoglu, F.; Choudhary, M.I. Isoflavonoid Glycosides from the Rhizomes of Iris germanica. Helvetica Chim. Acta 2003, 86, 3354-3362. [CrossRef]

18. Abu-Dahab, R. Antiproliferative activity of selected medicinal plants of Jordan against a breast adenocarcinoma cell line (MCF7). Sci. Pharm. 2007, 75, 121-136. [CrossRef]

19. Halpert, M.; Abu-Abied, M.; Avisar, O.; Moskovitz, Y.; Altshuler, O.; Cohen, A.; Weissberg, M.; Riov, J.; Gottlieb, H.E.; Perl, A.; et al. Rac-dependent doubling of HeLa cell area and impairment of cell migration and cell cycle by compounds from Iris germanica. Protoplasma 2011, 248, 785-797. [CrossRef]

20. Nadaroğlu, H.; Demir, Y.; Demir, N. Antioxidant and radical scavenging properties of Iris germanica. Pharm. Chem. J. 2007, 41, 409-415. [CrossRef]

21. Ullah, F.; Ayaz, M.; Sadiq, A.; Hussain, A.; Ahmad, S.; Imran, M.; Zeb, A. Phenolic, flavonoid contents, anticholinesterase and antioxidant evaluation of Iris germanica var; florentina. Nat. Prod. Res. 2015, 30, 1440-1444. [CrossRef]

22. Basgedik, B.; Ugur, A.; Sarac, N.; Burcu, B.; Aysel, U.; Nurdan, S. Antimicrobial, antioxidant, antimutagenic activities, and phenolic compounds of Iris germanica. Ind. Crop. Prod. 2014, 61, 526-530. [CrossRef]

23. Asghar, S.F.; Aziz, S.; Habib-Ur-Rehman; Ahmed, I.; Hussain, H.; Rahman, A.-U.; Choudhary, M.I. Secondary metabolites isolated from Iris germanica. Rec. Nat. Prod. 2009, 3, 139-152.

24. Ibrahim, S.R.M.; Mohamed, G.A.A.; Al Musayeib, N.M. New Constituents from the Rhizomes of Egyptian Iris germanica L. Molecules 2012, 17, 2587-2598. [CrossRef] [PubMed]

25. Orhan, I.E.; Nasim, S.; Tener, B.; Ayanoglu, F.; Özgüven, M.; Choudhary, M.I.; Rahman, A.-U. Two isoflavones and bioactivity spectrum of the crude extracts of Iris germanica rhizomes. Phytotherapy Res. 2003, 17, 575-577. [CrossRef] [PubMed]

26. Uzair, A.; Bakht, J.; Iqbal, A.; Naveed, K.; Ali, N. In vitro antimicrobial activities of different solvent extracted samples from Iris germanica. Pak. J. Pharm. Sci. 2016, 29, 145-150. [PubMed]

27. Sala, E.; Guasch, L.; Iwaszkiewicz, J.; Mulero, M.; Salvadó, M.J.; Bladé, C.; Ceballos, M.; Valls, C.; Zoete, V.; Grosdidier, A.; et al. Identification of human IKK-2 inhibitors of natural origin (Part II): In Silico prediction of IKK-2 inhibitors in natural extracts with known anti-inflammatory activity. Eur. J. Med. Chem. 2011, 46, 6098-6103. [CrossRef]

28. Hoang, L.; Beneš, F.; Fenclova, M.; Kronusova, O.; Švarcová, V.; Řehořová, K.; Švecová, E.B.; Vosátka, M.; Hajslova, J.; Kaštánek, P.; et al. Phytochemical Composition and In Vitro Biological Activity of Iris spp. (Iridaceae): A New Source of Bioactive Constituents for the Inhibition of Oral Bacterial Biofilms. Antibiot. 2020, 9, 403. [CrossRef]

29. Muto, Y.; Ichikawa, H.; Kitagawa, O.; Kumagai, K.; Watanabe, M.; Ogawa, E.; Seiki, M.; Shirataki, Y.; Yokoe, I.; Komatsu, M.; et al. Studies on Antiulcer Agents. I. The Effects of Various Methanol and Aqueous Extracts of Crude Drugs on Antiulcer Activity. Yakugaku Zasshi 1994, 114, 980-994. [CrossRef]

30. Choudhary, M.I.; Naheed, S.; Jalil, S.; Alam, J.M.; Rahman, A.-U. Effects of ethanolic extract of Iris germanica on lipid profile of rats fed on a high-fat diet. J. Ethnopharmacol. 2005, 98, 217-220. [CrossRef]

31. Singab, A.N.B.; Ahmed, A.H.; Sinkkonen, J.; Ovcharenko, V.; Pihlaja, K. Molluscicidal Activity and New Flavonoids from Egyptian Iris germanica L. (var. alba). Z. Naturforsch. C 2006, 61, 57-63. [CrossRef]

32. Borhani, M.; Sharifzadeh, M.; Farzaei, M.H.; Narimani, Z.; Sabbaghziarani, F.; Gholami, M.; Rahimi, R. Protective effect of Iris germanica L. in $\beta$-amyloid-induced animal model of alzheimer's disease. Afr. J. Tradit. Complement. Altern. Med. 2017, 14, 140-148. [CrossRef]

33. Rahman, A.-U.; Nasim, S.; Baig, I.; Jahan, I.A.; Sener, B.; Orhan, I.; Choudhary, M.I. Isoflavonoid glycosides from the rhizomes of Iris germanica. Chem. Pharm. Bull. 2002, 50, 1100-1102. [CrossRef]

34. Xie, G.-Y.; Qin, X.-Y.; Liu, R.; Wang, Q.; Lin, B.-B.; Wang, G.-K.; Xu, G.-K.; Wen, R.; Qin, M. New isoflavones with cytotoxic activity from the rhizomes of Iris germanica L. Nat. Prod. Res. 2013, 27, 2173-2177. [CrossRef] [PubMed]

35. Xie, G.-Y.; Chen, Y.-J.; Wen, R.; Xu, J.-Y.; Wu, S.-S.; Qin, M.-J. Chemical constituents from rhizomes of Iris germanica. China J. Chin. Mater. Medica 2014, 39, 846-850.

36. Kawase, A.; Ohta, N.; Yagishita, K. On the Chemical Structure of a New Isoflavone Glucoside, Homotectoridin, Isolated Together with Tectoridin from the Rhizomes of Iris germanica Linnaeus. Agric. Biol. Chem. 1973, 37, 145-150. [CrossRef]

37. Ali, A.; Elemary, N.; Elmoghazi, M.; Darwish, F.; Frahm, A. Three isoflavonoids from Iris germanica. Phytochemistry 1983, 22, 2061-2063. [CrossRef] 
38. Ibrahim, S.R.M.; Mohamed, G.A.; Zayed, M.F.; Ross, S.A. 8-Hydroxyirilone 5-methyl ether and 8-hydroxyirilone, new antioxidant and $\alpha$-amylase inhibitors isoflavonoids from Iris germanica rhizomes. Bioorganic Chem. 2017, 70, 192-198. [CrossRef]

39. Akashi, T.; Ishizaki, M.; Aoki, T.; Ayabe, S.-I. Isoflavonoid production by adventitious root cultures of Iris germanica (Iridaceae). Plant. Biotechnol. 2005, 22, 207-215. [CrossRef]

40. Ibrahim, S.R.M.; Al-Ahdal, A.; Khedr, A.; Mohamed, G.A.A. Antioxidant $\alpha$-amylase inhibitors flavonoids from Iris germanica rhizomes. Rev. Bras. Farm. 2017, 27, 170-174. [CrossRef]

41. Mohamed, G.A.; Ibrahim, S.R.; Ross, S.A. New ceramides and isoflavone from the Egyptian Iris germanica L. rhizomes. Phytochem. Lett. 2013, 6, 340-344. [CrossRef]

42. Wollenweber, E.; Stevens, J.F.; Klimo, K.; Knauft, J.; Frank, N.; Gerhäuser, C. Cancer Chemopreventive in vitro Activities of Isoflavones Isolated from Iris germanica. Planta Medica 2003, 69, 15-20. [CrossRef]

43. Nazir, N.; Koul, S.; Qurishi, M.A.; Taneja, S.C.; Ahmad, S.F.; Khan, B.; Bani, S.; Qazi, G.N. Immunomodulatory activity of isoflavones isolated from Iris germanica (Iridaceae) on T-lymphocytes and cytokines. Phytotherapy Res. 2009, $23,428-433$. [CrossRef]

44. Roger, B.; Jeannot, V.; Fernandez, X.; Cerantola, S.; Chahboun, J. Characterisation and Quantification of Flavonoids in Iris germanica L. and Iris pallida Lam. Resinoids from Morocco. Phytochem. Anal. 2012, 23, 450-455. [CrossRef]

45. Pailer, M.; Franke, F. Constituents of Iris germanica. Monatsh. Chem. 1973, 104, 1394-1408. [CrossRef]

46. Asghar, S.F.; Rehman, H.-U.; Rahman, A.-U.; Choudhary, M.I. Phytochemical investigations on Iris germanica. Nat. Prod. Res. 2010, 24, 131-139. [CrossRef] [PubMed]

47. Alam, A.; Verma, M.; Naik, K.K.; Choudhary, D.; Kumar, S. Anti-osteoporotic activity of isoflavones from Iris germanica targeting NF-kappaB. Int. J. Pharm. Investig. 2019, 8, 122-129. [CrossRef]

48. Xin, R.-h.; Zheng, J.-f.; Cheng, L.; Peng, W.-j.; Luo, Y.-j. Belamcanda chinensis (L.) DC: Ethnopharmacology, phytochemistry and pharmacology of an important traditional Chinese medicine. Afr. J. Tradit. Complement. Altern. Med. 2015, 12, 39-70.

49. Wuttke, W.; Jarry, H.; Popp, M.; Christoffel, V.; Spengler, B. Use of Extracts and Preparation from Iris Plants and Tectorigenin as Medicaments. U.S. Patent 20040176310, 15 May 2002.

50. Choudhary, D.; Alam, A. Pharmacology and phytochemistry of isoflavonoids from Iris species. J. Pharm. Clin. Res. 2017, 3, 555609.

51. Kang, K.A.; Zhang, R.; Piao, M.J.; Ko, D.O.; Wang, Z.H.; Kim, B.J.; Park, J.W.; Kim, H.S.; Kime, D.H.; Hyun, J.W. Protective ef-fect of irisolidone, a metabolite of kakkalide, against hydrogen peroxide induced cell damage via antioxidant effect. Bioorg. Med. Chem. 2008, 16, 1133-1141. [CrossRef] [PubMed]

52. Kawase, A.; Yagishita, K. On the structure of a new C-Glycosyl flavone, embinin, isolated from the petals of Iris germanica Linnaeous. Agric. Biol. Chem. 1968, 32, 537-538. [CrossRef]

53. Hilsenbeck, R.A.; Mabry, T.J. C-glycosylflavones from Siphonoglossa sessilis. Phytochemistry 1983, 22, 2215-2217. [CrossRef]

54. Harborne, J.B. Comparative Biochemistry of the Flavonoids; Academic Press: London, UK, 1967; p. 383. ISBN 01-232-4650-4.

55. Xie, G.; Qin, X.; Chen, Y.; Wen, R.; Wu, S. Alkaloids from the Rhizomes of Iris germanica. Chem. Nat. Compd. 2017, 53, 196-198. [CrossRef]

56. Jaenicke, L.; Marner, F.-J. The irones and their origin. Pure Appl. Chem. 1990, 65, 1365-1368. [CrossRef]

57. Benoit-Vical, F.; Imbert, C.; Bonfils, J.-P.; Sauvaire, Y. Antiplasmodial and antifungal activities of iridal, a plant triterpenoid. Phytochemistry 2003, 62, 747-751. [CrossRef]

58. Bonfils, J.-P.; Sauvaire, Y. Localization of iridals in Iris germanica rhizomes. Phytochemistry 1996, 41, 1281-1285. [CrossRef]

59. Bonfils, J.-P.; Pinguet, F.; Culine, S.; Sauvaire, Y. Cytotoxicity of Iridals, Triterpenoids from Iris, on Human Tumor Cell Lines A2780 and K562. Planta Medica 2001, 67, 79-81. [CrossRef] [PubMed]

60. Miyake, Y.; Ito, H.; Yoshida, T. Identification of iridals as piscicidal components of Iridaceous plants and their conformations associated with CD spectra. Can. J. Chem. 1997, 75, 734-741. [CrossRef]

61. Marner, F.J.; Krick, W.; Gellrich, B.; Jaenicke, L.; Winter, W. Irigermanal and iridogermanal: Two new triterpenoids from rhizomes of Iris germanica L. J. Org. Chem. 1982, 47, 2531-2536. [CrossRef]

62. Ito, H.; Miyake, Y.; Yoshida, T. New piscicidal triterpenes from Iris germanica. Chem. Pharm. Bull. 1995, 43, 1260-1262. [CrossRef]

63. Potterat, O.; Herzog, C.; Raith, M.; Ebrahimi, S.N.; Hamburger, M. Irigermanone, a Noriridal with Unprecedented Methylketone Function, from Iris germanica. Helvetica Chim. Acta 2014, 97, 32-38. [CrossRef]

64. Orhan, I.; Sener, B.; Hashimoto, T.; Asakawa, Y.; Ozgüven, M.; Ayanoğlu, F. Iristectorone K, a novel monocyclic triterpene ester from Iris germanica rhizomes growing in Turkey. Fitoterapia 2002, 73, 316-319. [CrossRef]

65. Muto, Y.; Ichikawa, H.; Seiki, M.; Shirataki, Y.; Yokoe, I.; Komatsu, M. Studies on Antiulcer Agents. II. Synthesis and Antiulcer Activity of Phenylpropanol Derivatives. Yakugaku Zasshi 1994, 114, 995-1004. [CrossRef]

66. Maurer, B.; Hauser, A.; Froidevaux, J.-C. New Irone-Related Constituents from the essential oil of Iris germanica L. Helvetica Chim. Acta 1989, 72, 1400-1415. [CrossRef]

67. Bonfils, J.-P.; Bonfils, C.; Larroque, C.; Surjus, A.; Gleize, D.; Sauvaire, Y. Lipid composition of microsomes of Iris germanica rhizomes. Phytochemistry 1995, 38, 585-587. [CrossRef]

68. Davoust, D.; Massias, M.; Molho, D. ${ }^{13}$ C-NMR investigation of flavonoid C- $\beta$-D-glucosides. Detection of a conformational equilibrium. Magn. Reson. Chem. 1980, 13, 218-219. [CrossRef]

69. Cheng, G.; Bai, Y.; Zhao, Y.; Tao, J.; Liu, Y.; Tu, G.; Ma, L.; Liao, N.; Xu, X. Flavonoids from Ziziphus jujuba Mill var. spinosa. Tetrahedron 2000, 56, 8915-8920. [CrossRef] 
70. Bjorøy, Ø.; Rayyan, S.; Fossen, T.; Kalberg, K.; Andersen, Ø.M. C-glycosyl anthocyanidins synthesized from C-glycosylflavones. Phytochemistry 2009, 70, 278-287. [CrossRef]

71. Quintão, N.L.M.; Meyre-Silva, C.; Silva, G.F.; Antonialli, C.S.; Rocha, L.W.; Lucinda-Silva, R.M.; Malheiros, A.; Souza, M.M.; Filho, V.C.; Bresolin, T. Aleurites moluccana (L.) Willd. Leaves: Mechanical Antinociceptive Properties of a Standardized Dried Extract and Its Chemical Markers. Evid. Based Complement. Altern. Med. 2011, 2011, 1-10. [CrossRef] [PubMed]

72. Frank, J.H.; Powder-George, Y.L.; Ramsewak, R.S.; Reynolds, W.F. Variable Temperature ${ }^{1} \mathrm{H}-\mathrm{NMR}$ Studies on Two CGlycosylflavones. Molecules 2012, 17, 7914-7926. [CrossRef] [PubMed]

73. Fan, J.-S.; Lee, I.-J.; Lin, Y.-L. Flavone glycosides from commercially available Lophatheri herba and their chromatographic fingerprinting and quantitation. J. Food Drug Anal. 2015, 23, 821-827. [CrossRef] [PubMed]

74. Shirane, S.; Ohya, S.; Matsuo, T.; Hirose, R.; Koga, D.; Ide, A.; Yagishita, K. C-Glycosyl compounds in the leaves of Gemmingia chinensis O. KUNTZE. Agric. Biol. Chem. 1982, 46, 2595-2597. [CrossRef]

75. Ames, B.N. Dietary carcinogens and anticarcinogens. Oxygen radicals and degenerative diseases. Science 1983, 221, 1256-1264. [CrossRef] [PubMed]

76. Reuter, S.; Gupta, S.C.; Chaturvedi, M.M.; Aggarwal, B.B. Oxidative stress, inflammation, and cancer: How are they linked? Free Radicals Biol. Med. 2010, 49, 1603-1616. [CrossRef] [PubMed]

77. Odunola, O.; Olugbami, J.O.; Gbadegesin, M.A. In vitro free radical scavenging and antioxidant properties of ethanol extract of Terminalia glaucescens. Pharmacogn. Res. 2015, 7, 49-56. [CrossRef]

78. Sun, L.; Zhang, J.; Lu, X.; Zhang, L.; Zhang, Y. Evaluation to the antioxidant activity of total flavonoids extract from persimmon (Diospyros kaki L.) leaves. Food Chem. Toxicol. 2011, 9, 2689-2696. [CrossRef]

79. Umamaheswari, M.; Chatterjee, T.K. In vitro antioxidant activities of the fractions of Coccinia grandis L. leaf extract. Afr. J. Tradit. Complement. Altern. Med. 2008, 5, 61-73. [CrossRef]

80. Gilardoni, G.; Chiriboga, X.; Finzi, P.V.; Vidari, G. New 3,4-Secocycloartane and 3,4-Secodammarane Triterpenes from the Ecuadorian Plant Coussarea macrophylla. Chem. Biodivers. 2015, 12, 946-954. [CrossRef] [PubMed]

81. De Rosa, S.; De Giulio, A.; Tommonaro, G. Aliphatic and aromatic glycosides from the cell cultures of Lycopersicon esculentum. Phytochemistry 1996, 42, 1031-1034. [CrossRef]

82. Ersöz, T.; Harput, Ü.Ş.; Saragoğlu, İ.; Çaliş, I.; Ogihara, Y. Phenolic compounds from Scutellaria pontica. Turk. J. Chem. 2002, 26, 581-588.

83. Zhou, G.; Yan, R.; Wang, X.; Li, S.; Lin, J.; Liu, J.; Zhao, Z. The overlooked rotational isomerism of C-glycosyl flavonoids. Phytochem. Rev. 2019, 18, 443-461. [CrossRef]

84. Liu, W.-B.; Hu, L.; Hu, Q.; Chen, N.-N.; Yang, Q.-S.; Wang, F.-F. New Resveratrol Oligomer Derivatives from the Roots of Rheum ihasaense. Molecules 2013, 18, 7093-7102. [CrossRef] [PubMed]

85. Ngoc, T.M.; Hung, T.M.; Thuong, P.T.; Na, M.; Kim, H.; Ha, D.T.; Min, B.-S.; Minh, P.T.H.; Bae, K. Inhibition of human low density lipoprotein and high density lipoprotein oxidation by oligostilbenes from rhubarb. Biol. Pharm. Bull. 2008, 31, 1809-1812 [CrossRef] [PubMed]

86. Kanchanapoom, T.; Suga, K.; Kasai, R.; Yamasaki, K.; Kamel, M.S.; Mohamed, M.H. Stilbene and 2-arylbenzofuran glucosides from the rhizomes of Schoenocaulon officinale. Chem. Pharm. Bull. 2002, 50, 863-865. [CrossRef] [PubMed]

87. Bai, X.; Qu, J.-L.; Liu, J.; Sun, J.-H.; Yuan, D. Isolation and identification of urinary metabolites of tectoridin in rats. J. Asian Nat. Prod. Res. 2011, 13, 604-610. [CrossRef]

88. He, M.; Min, J.-W.; Kong, W.-L.; He, X.-H.; Li, J.-X.; Peng, B.-W. A review on the pharmacological effects of vitexin and iso-vitexin. Fitoterapia 2016, 115, 74-85. [CrossRef]

89. Ganesan, K.; Xu, B. Molecular targets of vitexin and isovitexin in cancer therapy: A critical review. Ann. N. Y. Acad. Sci. 2017, 1401, 102-113. [CrossRef] [PubMed]

90. Lee, H.E.; Jeon, S.J.; Ryu, B.; Park, S.J.; Ko, S.Y.; Lee, Y.; Kim, E.; Lee, S.; Kim, H.; Jang, D.; et al. Swertisin, a C-glucosylflavone, ameliorates scopolamine-induced memory impairment in mice with its adenosine A1 receptor antagonistic property. Behav. Brain Res. 2016, 306, 137-145. [CrossRef]

91. Wu, C.; Shen, J.; He, P.; Chen, Y.; Li, L.; Zhang, L.; Li, Y.; Fu, Y.; Dai, R.; Meng, W.; et al. The $\alpha$-glucosidase inhibiting isoflavones isolated from Belamcanda chinensis leaf extract. Rec. Nat. Prod. 2012, 6, 110-120.

92. Choi, C.W.; Cha, M.-R.; Park, J.H.; Kim, Y.S.; Yon, G.H.; Hong, K.S.; Ryu, S.Y. Glucosidase Inhibitors from Seed Extract of Paeonia lactiflora. J. Korean Soc. Appl. Biol. Chem. 2009, 52, 638-642. [CrossRef]

93. Wu, Y.; Li, S.; Liu, J.; Liu, X.; Ruan, W.; Lu, J.-W.; Liu, Y.; Lawson, T.; Shimoni, O.; Lovejoy, D.B.; et al. Stilbenes from Veratrum maackii Regel Protect against Ethanol-Induced DNA Damage in Mouse Cerebellum and Cerebral Cortex. ACS Chem. Neurosci. 2018, 9, 1616-1624. [CrossRef]

94. Falomir, E.; Lucas, R.; Peñalver, P.; Martí-Centelles, R.; Dupont, A.; Zafra-Gómez, A.; Carda, M.; Morales, J.C. Cytotoxic, Antiangiogenic and Antitelomerase Activity of Glucosyl- and Acyl- Resveratrol Prodrugs and Resveratrol Sulfate Metabolites. ChemBioChem 2016, 17, 1343-1348. [CrossRef] 